\title{
Assessing Effects of Sediment Delivery to Coral Reefs: A Caribbean Watershed Perspective
}

\author{
Caroline S. Rogers ${ }^{1 * t}$ and Carlos E. Ramos-Scharrón ${ }^{2 \dagger}$ \\ ${ }^{1}$ Wetland and Aquatic Research Center, U.S. Geological Survey, St. John, VI, United States, ${ }^{2}$ Department of Geography \\ and the Environment and LLILAS-Benson, The University of Texas at Austin, Austin, TX, United States
}

OPEN ACCESS

Edited by:

Carla Zilberberg,

Federal University of Rio de Janeiro,

Brazil

Reviewed by:

Robert H. Richmond,

University of Hawai'i at Mānoa,

United States

Katie L. Cramer,

Arizona State University, United States

*Correspondence:

Caroline S. Rogers

caroline_rogers@usgs.gov

${ }^{t}$ These authors have contributed

equally to this work

Specialty section:

This article was submitted to

Coral Reef Research,

a section of the journal

Frontiers in Marine Science

Received: 10 September 2021

Accepted: 29 December 2021

Published: 28 January 2022

Citation:

Rogers CS and

Ramos-Scharrón CE (2022)

Assessing Effects of Sediment

Delivery to Coral Reefs: A Caribbean

Watershed Perspective.

Front. Mar. Sci. 8:773968.

doi: 10.3389/fmars.2021.773968
Coral reefs in the western Atlantic and Caribbean are deteriorating primarily from disease outbreaks, increasing seawater temperatures, and stress due to land-based sources of pollutants including sediments associated with land use and dredging. Sediments affect corals in numerous ways including smothering, abrasion, shading, and inhibition of coral recruitment. Sediment delivery resulting in deposition and water quality deterioration can cause degradation at the spatial scale of corals or entire reefs. We still lack rigorous longterm studies of coral cover and community composition before, during and after major sediment stress, and evidence of recovery after watershed management actions. Here we present an overview of the effects of terrestrial sediments on corals and coral reefs, with recent advances in approaches to watershed assessment relevant to the delivery of sediments to these ecosystems. We present case studies of northeastern Caribbean watersheds to illustrate challenges and possible solutions and to draw conclusions about the current state of knowledge of sediment effects on coral reefs. With a better understanding of erosion and the pathways of sediment discharge to nearshore reefs, there is the increased potential for management interventions.

Keywords: watersheds, sediment delivery, threshold, corals, coral reefs, thresholds and ecosystem resilience, runoff

\section{INTRODUCTION}

Sediments have long been considered a primary source of stress on corals and coral reefs (e.g., Johannes, 1975; Hatcher et al., 1989; Rogers, 1990; Ginsburg, 1993; Wilkinson, 2008). Almost 50 years ago, Johannes (1975) stated "Exposure of reefs to brackish, silt-laden water associated with flood runoff has probably been the single greatest cause of reef destruction historically." Coral reefs particularly in the western Atlantic and Caribbean are now deteriorating primarily from severe disease outbreaks and the effects of increasing sea water temperatures (Miller et al., 2009; Eakin et al., 2010; Muller et al., 2020). However, sediment stress remains critically important in many locations and is more tractable to management than thermal stress and diseases (Spalding and Brown, 2015; Bruno and Valdivia, 2016).

Sediments are a natural component of coral reefs and are generated even by undisturbed watersheds. Carbonate sediments, which can be re-suspended by waves, arise from the breakdown of calcifying reef organisms and are an important building block for reef construction, when they are cemented in place by coralline algae and abiotic processes (Hubbard, 1997). Terrigenous (i.e., terrestrial, land-derived) sediments originate as a combination of organic and inorganic materials largely eroded by overland flow, landslides, and streambank erosion (McKergow et al., 2005). Although controlled by complex processes, sediment delivery from watersheds to coastal waters 
represents the balance between the mass of sediment being eroded and that being retained by sediment sinks (such as floodplains, salt ponds, and coastal wetlands; de Vente et al., 2007).

Increased sediment exposure may occur as a result of enhanced erosion related to land use (Neil et al., 2002; Syvitski and Kettner, 2011), reductions in the sedimentcapturing capacity of fluvial and coastal environments (Adame et al., 2010), increases in precipitation with changing climate (Nearing et al., 2004), and dredging (Jones et al., 2016), along with increased storminess that can affect marine sediment transport, scouring, and burial (Harmelin-Vivien, 1994). We differentiate accumulation of sediment particles (sedimentation) from suspension in the water column (turbidity) although both can have adverse lethal or sublethal effects. Sediment stress can be defined as the response of an organism to sediment exposure, involving diversion of energy from important functions like reproduction and growth in an attempt to maintain homeostasis (Selye, 1956; Odum, 1967; Lugo et al., 1981).

Sediments do not always result in adverse effects. Some studies report positive effects of sediments in reducing thermal stress (Oxenford and Vallès, 2016). Suspended sediments can reduce irradiance through shading, ameliorating the thermal stress that triggers bleaching (van Woesik et al., 2012; García-Sais et al., 2017). Some reefs persist in chronically turbid environments where waves resuspend primarily non-terrigenous sediments and corals have adapted to wide fluctuations in sediment exposure (; Anthony and Larcombe, 2000; Larcombe et al., 2001).

Sediments can affect corals in numerous lethal and sub-lethal ways including smothering, abrasion, shading and inhibition of coral recruitment. Sediment delivery resulting in deposition and deterioration of water quality also can cause degradation at the spatial scale of an entire reef (including organisms other than corals) and the overall seascape including reefs and seagrass beds (Cabaço et al., 2008). Over 45 years ago, Johannes (1975) stated that "the resistance of this community [referring to reefs and associated habitats] to environmental stresses cannot exceed that of its coral component."

Reefs are usually subjected to several stressors at a time, some with synergistic interactions, making distinguishing the sediment effects difficult. In particular, it can be challenging to differentiate the response to sediments from that to freshwater, sewage, nutrients, or oil drilling-fluid components (Pastorok and Bilyard, 1985; Hallock and Schlager, 1986). Sediments often contain nutrients and the effects of sedimentation cannot always be differentiated from those associated with eutrophication (Fabricius, 2011). Unlike acute stressors such as hurricanes, excessive sedimentation can be both acute and chronic, persisting for years as sediments are re-suspended, lowering light levels and making substrata unsuitable for coral settlement.

Given the inherent complexity of coral reefs, their lack of a sediment-specific response, the variety of existing stressors, and the challenges in accurately documenting sediment exposure levels, it is not surprising that distinguishing the responses of reef organisms and of the overall reef ecosystem to the specific effects of sediments remains challenging. Only limited data are available on the drivers of coral mortality, in particular local stressors such as sedimentation and nutrients, because of a lack of comprehensive and statistically-based monitoring over necessary spatial and temporal scales and hypothesis-driven experimental research (Bruno and Valdivia, 2016; Rogers and Miller, 2016).

This paper focuses on terrigenous sediments delivered in runoff from discrete watersheds to nearshore waters in the U.S. Virgin Islands (USVI; Rogers et al., 2008) and Puerto Rico (PR; Ballantine et al., 2008), and not on resuspension of terrigenous and carbonate sediments as described by Larcombe et al. (2001) for Great Barrier Reef reefs in highly turbid environments. Although we have made progress in elucidating the effects of sediments on these diverse marine ecosystems (see reviews by Rogers, 1990; Fabricius, 2005; Erftemeijer et al., 2012), we still have much to learn. The goal of this article is to present an overview of our present understanding of the effects of terrestrial sediments on corals and coral reefs, with watershed assessment approaches relevant to the delivery of sediments to these ecosystems. We discuss basic principles related to watershed-scale sediment budget analyses and recent literature describing advances in watershed management that result in reduction of sediment input to coral reefs, with an emphasis on selected locations in the northeastern Caribbean. We present specific case studies of small Caribbean watersheds to illustrate some of the challenges and their possible management solutions. While recognizing the difficulties inherent in understanding such complex effects and processes, and the limitations of our knowledge, it is possible to make some consequential management recommendations.

\section{EFFECTS OF SEDIMENTS ON CORALS AND CORAL REEFS}

\section{Effects of Sediments on Corals}

Several studies have described the effects of sediments on corals, but we will not review them all here (see Johannes, 1975; Rogers, 1990; Fabricius, 2005; Erftemeijer et al., 2012 and references cited therein). Once sediments enter the marine environment, they can settle directly on corals and other reef organisms or remain in suspension, reducing the light required for photosynthesis, growth and calcification (Cortés and Risk, 1985; Richmond, 1993). Sediment characteristics including size, color, and mineralogy dictate settling/suspension dynamics and light attenuation capacities (Storlazzi et al., 2015). The coarse fraction $(\sim>2 \mathrm{~mm})$ settles on the bottom where it can smother and abrade corals during high-energy events (Jones et al., 2016). Finer sediments $(\sim<0.0625 \mathrm{~mm})$ tend to remain in suspension longer and can easily become resuspended (Ogston et al., 2004; Storlazzi et al., 2009) reducing light penetration over long distances $(\sim 10 \mathrm{~s} \mathrm{~km})$ offshore or down-current from points of delivery depending on river flow and ocean currents (Restrepo et al., 2016; Tarya et al., 2018; Torres-Pérez et al., 2021). Fine sediment particles settling on corals also can enhance bacterial activity on coral tissue (Risk and Edinger, 2011) and can expose corals to dissolved substances, trace metals, and other contaminants such as pesticides that may adhere to clay minerals 
(Glynn et al., 1989; Pait et al., 2012; Whitall et al., 2014; Jones et al., 2020).

Studies have been conducted in the laboratory and in the field. Interpretation of the results of laboratory manipulations must consider the types and particle sizes of sediments applied, the presence of contaminants, and the unnatural conditions (Hubbard and Pocock, 1972). Experiments in the field are difficult because of conditions which cannot be controlled as in a laboratory setting, such as water motion that can carry away applied sediments. Generalizations are difficult because studies have been done with terrestrial and marine sediments, with different coral species, with different particle sizes, with sediments alone or mixed with nutrients, and under both natural field conditions and in laboratories.

Corals have mechanisms to cope with sediments settling on polyps (e.g., cilia, mucus shedding, etc.) up to a point (e.g., Stafford-Smith and Ormond, 1992; Stafford-Smith, 1993). However, these all require expenditure of energy that could otherwise go into growth or other functions. Some studies describe experimental manipulations with terrestrial and marine sediments in the field or in the laboratory with a focus on short term exposure (days) to identify acute effects (Weber et al., 2006). In an early laboratory study of 26 coral species found in Florida, Hubbard and Pocock (1972) examined the sediment rejection capabilities after application of particles ranging from 62 to $2,000 \mu \mathrm{m}$. All of the species were able to reject silt-sized particles and most could reject all particle sizes. Only two species were described as poor or incompetent in rejecting sediments.

Building on these and similar studies, Erftemeijer et al. (2012) presented a synthesis of field and laboratory data on the sensitivity (as determined by minor sublethal to major lethal effects) of 46 coral species to turbidity and of 71 species to sedimentation. They assigned a score (the basis of which was not provided) to each species ranging from very tolerant to very sensitive, significantly including not only the exposure in terms of suspended matter and sediment input $\left(\mathrm{mg} \mathrm{cm}^{-2} \mathrm{day}^{-1}\right)$ but also the duration of exposure, and found a significant relationship between sensitivity and growth form, for example with branching species typically less affected than massive ones. Given the range of responses and the inherent complexity, this useful but somewhat subjective ranking could be improved through reexamination, updating and substantiation with empirical data.

Many studies provide useful data on tolerance to sediments but for only a few species (e.g., Rogers, 1983; Rice and Hunter, 1992). Morphology clearly is a factor. Branching corals are less likely to retain sediments resulting in smothering and partial mortality than more rounded, massive colonies (Rogers, 1983; Erftemeijer et al., 2012.) The focus of studies of the effects of suspended sediments or deposition should not just be on shortterm responses of adult corals, but also on coral growth rate and recruitment (see Jokiel et al., 2014; Perez et al., 2014; Jones et al., 2020) and changes in the ability to photosynthesize (see Phillip and Fabricius, 2003).

Sublethal responses of a limited number of Pacific and Atlantic coral species to sediments have been noted in several studies of coral photobiology, using PAM Fluorometry (Piniak and Storlazzi, 2008; Flores et al., 2012; Browne et al., 2014; Rushmore et al., 2021) and analysis of gene expression (Downs et al., 2012) suggesting that even when mortality does not occur, sediments can reduce overall energy available for growth and reproduction.

Sofonia and Unsworth (2010) proposed that accounting for duration of exposure to varying levels of Photosynthetically Available Radiation (PAR) provides a more meaningful metric to quantify the effects of turbidity than single threshold values. Such an approach could allow monitoring of light received by corals to define adverse levels of turbidity above which corals would be stressed, triggering specific management actions (Sofonia and Unsworth, 2010). Sofonia and Unsworth (2010) do not discuss how they quantified stress to corals or acknowledge how challenging this would be given that sublethal effects can affect reproduction and growth well before corals die partially or entirely.

Coral species differ in their ability to deal with sediment accumulation and with reduction of light transmissivity associated with turbidity. Species-specific tolerances, however, are not as well-studied as one might think given statements in the published literature. In general, presence or absence of particular coral species growing on a reef may not reveal that much about the environmental conditions or the stressors to which the corals are exposed and does not serve as a precise indicator of sediment conditions reflecting a gradient of sediment influence. We have to be cautious about thinking of certain species as "indicators." For example, there is evidence that Montastraea cavernosa is more resistant to sediments than some other species (Lasker, 1980), but that does not mean that its presence on a reef indicates that the reef has been subjected to sediment stress.

Although there is some evidence that coral species have different tolerances/sensitivities to suspended and accumulated sediments, currently no rigorous hierarchy or well-defined gradient of coral species responses to sediment accumulation or light attenuation exists. Susceptibility (or resistance) to sediment stress could vary for each species and could differ depending on reef location (i.e., proximity to shore, depth, wave action, etc.) and particular environmental conditions (Weil, 2021). However, large shifts in coral community composition, for example as revealed by cores, can indicate major changes in environmental factors such as a degradation in water quality (Duprey et al., 2016; Cybulski et al., 2020; Cramer et al., 2021).

\section{Effects of Sediments on Entire Reefs}

Stony corals are the architects of coral reefs, and as Bruno and Valdivia (2016) have concisely stated, "Coral loss is thus a direct measure of habitat degradation," and "Macroalgal cover is an indirect measure of reef degradation." In general, deterioration of coral reefs from excessive sedimentation or other causes, is reflected in declining amounts of coral and increasing amounts of algae (e.g., Rogers and Miller, 2006; Schutte et al., 2010; Jackson et al., 2014; Arias-González et al., 2017), although these changes are not always tightly linked. Not all shifts in relative abundance between benthic components involve corals and algae. In one study in Panama, the coral Agaricia tenuifolia replaced Porites over time apparently as a result of a loss of water quality with increased input of nutrients and sediments associated with agriculture and a rise in population density (Aronson et al., 2014). 
Large quantities of sediments (deposited or suspended in the water column) can lead to adverse reef-scale effects. These may include bleaching, reduced recruitment, collapse of physical structure with associated loss of ecological services, and loss of fish habitat with associated declines in abundance and species diversity (Erftemeijer et al., 2012). Several studies show a correlation between presumed (as opposed to measured) sediment exposure (along a distance-based gradient) and lower coral cover (coral abundance), lower recruitment, and more partial mortality (e.g., Acevedo et al., 1989; Ginsburg et al., 2001; Nugues and Roberts, 2003; Dikou and van Woesik, 2006a).

Establishing how much sediment is excessive, leading to adverse effects on structure or function, from either a terrestrial or marine perspective is difficult (Rodgers et al., 2012; Tuttle and Donahue, 2020). Watersheds and coral reefs are not commonly studied as connected systems simultaneously, particularly in the Caribbean. No rigorous, long-term comprehensive, before, during and after empirical study of the effects of dredging or increased/decreased terrestrial sediment discharge on the structure and function of a Caribbean coral reef has been published. Similarly, there is no rigorous analysis of changes in marine water quality or sedimentation rates and concomitant improvement in coral reef structure resulting from watershed management actions (Kroon et al., 2014).

With increasing sediment (or other) stress, coral species are unlikely to be replaced by other coral species. More often, the relative abundance of corals of different species changes as colonies become fragmented and portions of them die. Corals are modular, colonial organisms, remnants of which can persist after other portions die. In reefs off Okinawa, Japan, partial mortality was a better indicator of the deleterious effects of sediment-laden runoff than percent live cover, colony density, generic richness, or colony size (Dikou and van Woesik, 2006b).

High sediment exposure, from runoff of terrestrial sediments or dredging projects, can have direct and indirect effects on coral communities and nearby habitats. Direct effects include smothering and mortality of corals, while indirect effects include impairment of coral recruitment and associated alteration of colony size frequency distribution (Cortés and Risk, 1985). In a study of coral reefs along an inshore to offshore gradient in the USVI, Smith et al. (2008) noted more old coral mortality (i.e., partial and not recent) and bleaching nearshore suggesting a link with higher sediment exposure from land runoff. In a study of the effects of flooding in a small bay in Kauai, Hawaii, Storlazzi et al. (2009) documented survival of adult corals but burial of sites which would have been suitable for coral settlement. Small variations in hydrodynamic processes could drive considerable changes in rates of sediment deposition and resuspension (These studies found no correlation between sedimentation and coral diseases.) In a review of the effects of dredging near or on coral reefs, Erftemeijer et al. (2012, Table 1) noted a range from minimal effects to, in one case (in Bahrain), a major loss of 22 ha of coral reefs with an associated degradation of 8 ha nearby because of increased turbidity and sedimentation. Effects were both direct and indirect, with loss of coral and declines in fish abundance and diversity, and changes in water circulation. In some cases, seagrass beds and mangroves were affected.
An early focus on the direct effects of sediments on corals based on both laboratory and field studies has been followed by more recent studies of indirect effects on corals as well as effects on other reef-associated organisms. Fewer studies have focused on the interactions between sedimentation and other stressors. Sediments that accumulate on algae (filamentous turf or macroalgae) sometimes promote and sometimes inhibit algal growth with subsequent effects on coral growth and survival (Birrell et al., 2005; Muthukrishnan and Fong, 2014). Sediment particles also inhibit recruitment/settlement and survival of both algae and corals with long-term consequences for reef persistence or recovery (e.g., Bahr et al., 2015). Often terrestrial sediments contain organic matter or other pollutants, and the deleterious effects of sediments may be attributable more to these materials than to the sediment particles themselves (see van Dam et al., 2011). Macroalgae can cause detrimental effects beyond smothering and abrasion of corals and inhibition of coral recruitment. These include decreased coral growth (Burkepile and Hay, 2008), lowered fecundity (Foster et al., 2008), and greater mortality (Nugues and Bak, 2006; Smith et al., 2008).

Sediments can interact with other stressors such as overfishing to hinder coral growth, and it is difficult to quantify the interactive effects of local stressors (Bruno and Valdivia, 2016). Any stressor affecting the susceptibility of a coral (immune response, energy availability, pathogen virulence, etc.) could be a potential driver for a disease to develop. Some evidence indicates possible links between increased sedimentation and diseases of scleractinian corals, specifically black band disease (Littler and Littler, 1996; Bruckner et al., 1997). Sediments may be a reservoir for disease pathogens, and benthic algae may trap sediments harboring disease pathogens (Nugues et al., 2004; Voss and Richardson, 2006a; Haapkylä et al., 2011).

Some studies show increased disease prevalence with increase in nutrients specifically (Vega Thurber et al., 2014; Wear and Thurber, 2015). However, disease outbreaks occur in the absence of any obvious or rigorously documented stressor (with the exception of warming seawater temperatures). Currently extensive and rapid coral mortality in Florida and portions of the Caribbean is being driven more by stony coral tissue loss disease (Alvarez-Filip et al., 2019; Muller et al., 2020; Brandt et al., 2021) than any other stressor, but no link to any environmental factor has been discovered and verified.

The most urgent problem now affecting coral reefs in Florida and some portions of the Caribbean, including the USVI and $\mathrm{PR}$, is the advance of this stony coral tissue loss disease (SCTLD), first reported on Florida reefs in 2014 (Precht et al., 2016). Rates of coral mortality exceed any documented before, and some highly susceptible species are being eliminated from some locations. Although other less virulent diseases have been associated with sediment exposure or increased nutrient concentrations (Bruno et al., 2003; Kaczmarsky et al., 2005; Voss and Richardson, 2006b), and stony coral tissue loss disease has not been linked conclusively so far to any anthropogenic activity, sediment exposure, sewage, chemical pollutants, or any other environmental factor, and research continues. Recently viruses have been documented in endosymbionts in corals with SCTLD, but no definitive reason 
for a viral disease to appear in the endosymbionts has been determined (Work et al., 2021).

It is logical to think that increased sediment exposure as well as any other factor that stresses corals would increase their vulnerability to diseases, but the correlation between sedimentation and diseases is not well-documented (Sutherland et al., 2004). No studies rigorously show sediment stress from dredging or increased sediment discharge from watersheds is linked to disease outbreaks. One study of a reef in Barrow Island, Australia (Pollock et al., 2014) concluded that dredging had caused an increase in coral disease prevalence, but the study began a month after dredging ceased, and a second study in the same area saw increased coral mortality from dredging effects but no link between dredging and coral diseases (see detailed discussion in Stoddart et al., 2019). In a study of the effects of a major dredging project in Florida, a particularly virulent disease was associated with more coral mortality than sediment stress (Gintert et al., 2019).

\section{THRESHOLDS FOR CORAL SPECIES AND AN OVERALL REEF THRESHOLD}

What, conceptually, is a threshold for sediment exposure (including suspended sediments and deposition)? This could be defined as the rate of sediment accumulation or concentration of suspended matter over a given period of time which causes a range of stresses from physiological impairment to complete mortality. How might a threshold for a reef differ depending on the coral species composition, coral cover, and coral density? Are short-term, acute and infrequent pulses of sediments into the reef environment less detrimental than chronic sedimentation at lower levels? At what concentration of suspended sediments does coral growth cease? Does coral reef zonation shift to shallower depths with high turbidity? Rogers (1990) concluded: "Research should be designed to provide a basis for predicting the response of coral ecosystems to known inputs of sediments into reef waters from coastal development."

Some studies support the concept of an overall reef threshold by noting the distribution of reefs in relation to estimated natural rates of runoff (e.g., Hubbard, 1986; McLaughlin et al., 2003), with reefs generally not located where input of freshwater and associated sediments is high, and a correlation of higher coral cover with lower sediment input (e.g., Acevedo et al., 1989; van Woesik et al., 1999). However, some reefs appear to thrive in very turbid waters, particularly if fast currents are present to prevent sediment accumulation (e.g., Johannes, 1975; Woolfe and Larcombe, 1999).

The concept of a sediment deposition threshold may be useful in certain situations. For example, it may be possible to use threshold limits to guide dredging activities. Thresholds for corals are not the same as thresholds for entire reefs as reefs have different coral species composition and three-dimensional structure as well as environmental context. Sediment levels could differentially affect certain species that contribute in minor or major ways to the structure. On reefs in Indonesia subject to eutrophication and sedimentation, coral growth rates (i.e., linear extension) did not decrease but reef accretion/calcification rates did (Edinger et al., 2000). Instead of concluding that it is too complicated or unrealistic to set a threshold, the reality is that in certain situations, for example, dredging projects, it is undoubtedly important to determine one. It would be valuable to determine such a threshold in cases where dredging projects occur near coral reefs as dredging could be halted when thresholds are met or exceeded. (To our knowledge, this situation has never occurred.) Similarly, knowing the limit above which sediment exposure could adversely affect a reef near shore could guide decisions about coastal development projects and watersheds.

Threshold values (for direct mortality of tissue) have been determined for some coral species (Lirman and Manzello, 2009; reviewed in Erftemeijer et al., 2012), but these could vary greatly depending on the size and nature of the sediments and the field and laboratory conditions under which the corals were tested. Thresholds are usually defined by tissue loss (i.e., partial mortality) and not sublethal factors although decreases in net photosynthesis are also reported (see meta-analysis in Tuttle and Donahue, 2020). Fabricius (2005) proposed that thresholds for coral recruits are an order of magnitude lower than for adult corals.

In a 1990 paper, Rogers (1990) suggested that "normal" sedimentation rates for coral reefs appeared to be on the order of $10 \mathrm{mg} \mathrm{cm}^{-2} \mathrm{day}^{-1}$ or less, and typical total suspended solid concentrations less than $10 \mathrm{mg} \mathrm{L}^{-1}$ (Table 1 in Rogers, 1990), but noted that we do not know how high these concentrations and rates can go before reefs and reef organisms are adversely affected. Rather than providing definitive thresholds, Rogers (1990) highlighted an area for further analysis and research. For example, in this early paper, Table 1 provides sedimentation rates from only seven studies in five Caribbean locations and only one from the Pacific. Total suspended solids are provided for only two Caribbean islands. Note also that the duration, the time period, over which corals and reefs are exposed to sediments, whether settling or suspended in the water, is critical in determining the overall effects.

On the other hand, it is also worth noting that all these years later the values in Rogers (1990) based on so few locations and species have been useful indicators for describing levels at which perceived or documented coral stress has occurred (for example, see Dutra et al., 2006; Jokiel et al., 2014; Nelson et al., 2016; Tuttle and Donahue, 2020). Tuttle and Donahue (2020) did a comprehensive meta-analysis of 86 studies on the sublethal and lethal effects of suspended and deposited sediments considering magnitude and duration of exposure, on all coral stages, of 140 coral species, from the Atlantic, Pacific, and Indian Oceans (see Tuttle et al., 2020 for the review protocol). Key findings included the conclusion that "corals exposed to sediments at $10 \mathrm{mg} \mathrm{cm}^{-2}$ day $^{-1}$ have a $25.8-$ $35.9 \%$ probability of experiencing adverse effects." and "corals exposed to suspended sediments at $10 \mathrm{mg} \mathrm{L}^{-1}$ have an $8.2-10 \%$ probability of experiencing adverse effects." Tuttle and Donahue (2020) acknowledged that they did not achieve their stated goal of determining specific thresholds that would prompt management action and noted that we are still far from having the ability 
to separate additive and synergistic effects of multiple local stressors on coral reefs.

Erftemeijer et al. (2012) present thresholds for coral species and for coral reefs for total suspended solids and for sedimentation $\left(\mathrm{mg} \mathrm{cm}^{-2} \mathrm{day}^{-1}\right)$. However, it is unrealistic to think that single threshold values for particular species, which are difficult to derive (and would vary under different environmental conditions), could be used to establish universally meaningful threshold values for entire reef ecosystems which are highly diverse and include not only corals but sponges, gorgonians, algae, fish and other organisms. However, as noted above, clearly it would be valuable to have some kind of target level of turbidity/sediment deposition rate to indicate that a dredging operation or other activity should be stopped or that a corrective action is merited. Erftemeijer et al. (2012) stated "given the wide range of sensitivity levels among coral species and in baseline water quality conditions among reefs, meaningful criteria to limit the extent and turbidity of dredging plumes and their effects on corals will always require site-specific evaluations, taking into account the species assemblage present at the site and the natural variability of local background turbidity and sedimentation." Such site-specific thresholds would be valuable but not easily obtained.

Quantifying relationships between water quality deterioration or dredging impacts and effects on corals and other reef organisms requires the ability to isolate and measure sediment input, settling rates, and duration of exposure. Several papers discuss the use of sediment traps and can be consulted for details (Storlazzi et al., 2011; Risk, 2014). However, comments about the limitations of traps of certain dimensions should be considered in light of what one hopes to measure with themshorter traps will allow more sediments to escape under high wave/current conditions (as particles will not settle) but that will reflect more accurately what the surfaces of corals are exposed to. Measurement of suspended sediments is more straightforward, but different types of sediments will affect light transmission in various ways. The use of remote sensing techniques to monitor suspended sediment concentration and PAR are an appealing technique (Devlin et al., 2015; Hernández et al., 2020). However, data can be extracted only for areas not covered by clouds and their temporal resolution is not shorter than $24 \mathrm{~h}$ making them likely better suited for large areas and perennial streams than for small bays and ephemeral streams. The use of unmanned flying or aquatic drones for water quality monitoring might be a viable alternative (Demetillo and Taboada, 2019), but one that will be likely limited to very specific locations.

A new perspective points to a different kind of threshold, one that relates to the actual creation (accretion) and maintenance of reef structure (Stearn et al., 1977; Hubbard et al., 1990; Perry et al., 2012). A coral reef is the product of overall carbonate production minus losses to bioerosion and physical export. An estimate of the carbonate productivity of a reef can be derived from the abundance and calcification rates of individual organisms that precipitate calcium carbonate, primarily corals and coralline algae (Courtney et al., 2020). A budget can be calculated based on this and the export of sediment created by bioerosion. Perry et al. (2012) suggest that a live coral cover of $10 \%$ or more is essential to sustain reef accretion, but the different contributions of corals and other calcifying organisms must be factored in. This level of coral cover cannot guarantee active reef accretion but it provides a starting point for evaluating the status of a reef. Unfortunately, many reefs in the Caribbean have coral cover close to or below this value following thermal stress (bleaching) and disease events, hurricanes, local effects of sewage and sediment runoff, loss of herbivorous urchins and fishes, and other stressors, and coral cover is continuing to decline. Consequently, coral cover could decline to below (or be maintained at) a certain threshold (Perry et al., 2012) at which reef accretion switches to net erosion.

\section{WATERSHED-CENTERED SEDIMENT ASSESSMENTS: THE SCIENCE AND MANAGEMENT REALITIES}

Now we turn to a consideration of sediment assessments taking a watershed approach. After providing a general background, we present several case studies from the northeastern Caribbean that illustrate both the science and the management realities involved in understanding and limiting the effects of sediment delivery to nearshore waters supporting growth of coral reefs.

\section{General Background}

Terrestrial erosion refers to the wearing away of earthen materials by runoff, ice, wind, or gravity. Human effects on upland erosion vary with the type of activity and depend on landscape and climate characteristics (Ludwig and Probst, 1998; Syvitski et al., 2014). Erosion processes typically responsible for sediment discharge from watersheds to coral reefs include those induced by overland flow, streambank erosion, and landsliding (Figure 1). Not all eroded sediment reaches nearshore waters because it can be retained for variable periods by sediment sinks such as floodplains or wetlands (Walling, 1999). Sediment discharge represents the total mass of sediment delivered by a watershed per unit time (e.g., Megagrams per year $\left[\mathrm{Mg}=10^{6} \mathrm{~g}\right]$ ). The term sediment yield refers to the area-normalized discharge rate (e.g., $\mathrm{Mg} \mathrm{km}^{-2}$ year $^{-1}$; Milliman and Farnsworth, 2013). The term "runoff" refers simply to water flowing on the land surface and not to sediment discharge.

Runoff (i.e., freshwater) and sediment discharge from watersheds to coastal waters may be: (a) ephemeral (i.e., sporadically delivering runoff to coastal waters $\sim 10$ times per year during wet conditions and only for a few hours or days at a time. Examples of these are the watersheds draining the USVI and Oahu-Hawaii; Wolanski et al., 2009; RamosScharrón and LaFevor, 2016); (b) perennial (i.e., with constant streamflow year-round like many rivers draining Puerto Rico and Colombia; Larsen and Webb, 2009; Restrepo et al., 2016); or (c) a combination of both as is the case for Australian watersheds flowing toward the Great Barrier Reef (Joo et al., 2012). This is a relevant coral reef stress factor as the temporality of sediment delivery in part controls the nature (i.e., sporadic or chronic) and duration of exposure, factors known to determine sediment impacts on corals (Erftemeijer et al., 2012). However, neither sediment discharge rate nor its duration 

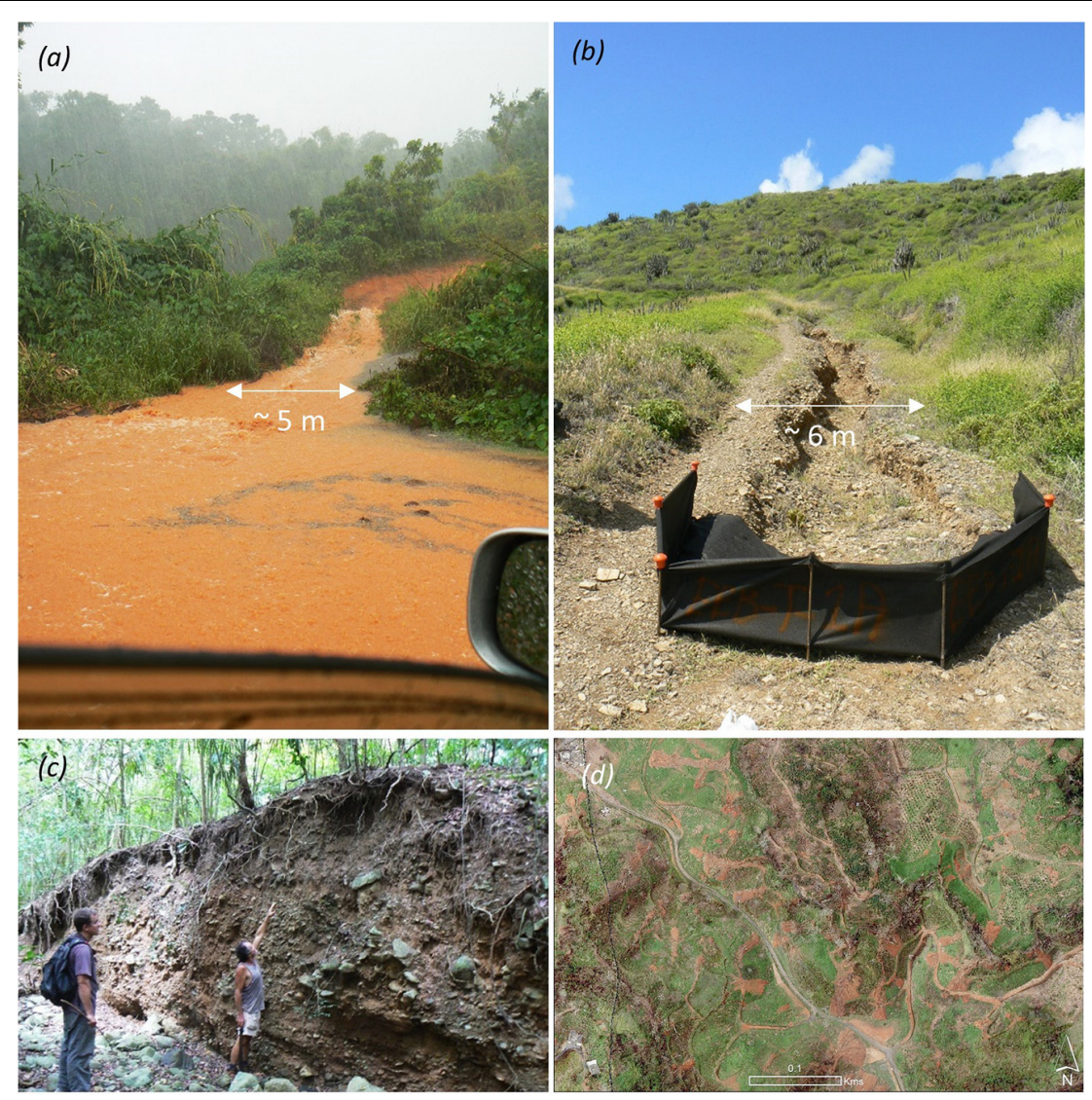

FIGURE 1 | Examples of erosion processes responsible for generating sediments that reach coral-reef ecosystems in the Northeastern Caribbean: (a) surface erosion due to overland flow on unpaved roads and agricultural areas (Río Grande de Añasco-PR); (b) gullying of footpaths (East End, St. Croix-USVI); (c) streambank erosion (Coral Bay, St. John-USVI); and (d) shallow landslides (Yauco-PR).

exactly equates to exposure levels as those also commonly depend on the distance from the outlet to the corals, sediment particle size distribution and mineralogy, and oceanic factors controlling direction, mode and rate of sediment transport and deposition.

The global peak of terrestrial sediment delivery to the oceans occurred during the first half of the 20th century (Hooke, 2000). This period predates the post-WWII proliferation of dams, which now act as sediment sinks that have reduced worldwide sediment discharge (Syvitski and Kettner, 2011). However, it has been known for a very long time (e.g., Marsh, 1867) that most coral reefs are far from the large watershed outlets included in these planetary-scale assessments (McLaughlin et al., 2003). Therefore, these global delivery estimates are not necessarily representative of sediment discharges to coral-bearing ocean waters (Browning and Sawyer, 2021). For example, there are numerous studies showing an acceleration of terrestrial sediment accumulation since the mid-20th century in marine environments of the northeastern Caribbean (e.g., Jessen et al., 2008; Ryan et al., 2008; Brooks et al., 2015). Although historical sediment delivery rates from coastal watersheds into nearshore systems have been documented at some locations (e.g., Bartley et al., 2018), limited empirical data exist for most coral reefs.
Watershed sediment discharges into coastal ecosystems can range significantly and corresponding impacts to corals are relatively unknown. Consequently, there is no specific watershed sediment discharge threshold above which it becomes deleterious to coral reefs. For example, sediment delivery from the $130,000 \mathrm{~km}^{2}$ Burdekin watershed in Australia averages 5.6 million $\mathrm{Mg}$ year ${ }^{-1}$ with disputable effects on the Great Barrier Reef (Neil et al., 2002; De'ath et al., 2012). In contrast, much smaller watersheds in moist to wet tropical areas of PR and St. Lucia have far lower sediment loads (ca. 5,000-450,000 Mg year ${ }^{-1}$ ) that are also believed to degrade corals (Larsen and Webb, 2009; Bégin et al., 2014). Similarly, sediment delivered to fringing reefs in the USVI is considered a threat to coral reefs despite delivery rates of only $20-275 \mathrm{Mg}$ year $^{-1}$ (RamosScharrón and MacDonald, 2007a). It is important to note that watershed discharge or yield rates are typically reported in units of $\mathrm{Mg}$ year ${ }^{-1}$ or $\mathrm{Mg} \mathrm{km}^{-2}$ year $^{-1}$, and while these are useful for communicating information among earth scientists, the meaning of these values in terms of coral stress is unknown. It is not known how these values translate into biologically-meaningful reductions in light transmissivity or sediment settling rates on corals occurring at higher temporal resolution (i.e., hours, days; Weber et al., 2006). 
Sediment discharge does not equal the sum of all erosion occurring within a watershed:

$$
\text { Sediment discharge } \neq \text { Erosion }
$$

where, "Erosion" is in units of mass per unit time (e.g., $\mathrm{Mg}$ year $^{-1}$ ) and equals the sum of all sediment produced by overland flow, landsliding, streambank erosion, and any other relevant erosive process. Sediment discharge ranges from $\sim 10$ to $\sim 100 \%$ of that eroded within the watershed (Walling, 1983) [although values $>100 \%$ have been reported (de Vente et al., 2007; Church, 2017)]. That is because, in broad terms, sediment discharge equals the difference between sediment released by erosion and that retained either briefly (i.e., hours to a few years) or over long-time frames (i.e., decades to thousands of years) by sediment sinks (e.g., bottom of hillslopes, floodplains, estuaries, salt ponds, etc.) (Meybeck and Vörösmarty, 2005). This can be expressed by the following equation:

$$
\text { Sediment Discharge }=\text { Erosion }-\Delta \text { Storage }
$$

where all terms are in units of mass per unit time (e.g., $\mathrm{Mg}$ year ${ }^{-1}$ ), "Sediment discharge" represents the rate of sediment output, "Erosion" is as defined for Equation 1, and " $\Delta$ Storage" is the change in sediment accumulation in sinks over the same time period represented by sediment discharge and erosion. $\Delta$ Storage values may be both positive or negative. A positive value indicates a gain in the amount of sediment stored [e.g., a river going over its banks and adding sediment to its floodplain (i.e., retention)], while a negative value means a loss of sediment storage [e.g., a river widening or changing course during a high flow event facilitated by cutting into (i.e., releasing) previously stored floodplain sediments]. Therefore, sediment delivery can increase by: (a) accelerated erosion, (b) a decrease in sediment storage (i.e., releases of sediments stored in sinks), (c) reductions in the trapping efficiency of sinks, or (d) increases in sediment transport capacity of rivers due to urbanization and channelization, changes in river geometry induced by extreme flood events, or increased flow rates associated with climate change (Wohl, 2015). Conversely, decreases in sediment output can occur by reduced erosion and/or gains in sediment storage.

The role of sediment storage is crucial in defining how any increases in erosion manifest themselves as sediment discharge. In cases where a large portion of the eroded sediments become stored for thousands of years, erosion can occur without any noticeable increases in sediment discharge (Fryirs et al., 2007). In cases where eroded sediment is stored for decades, these sediments can become an important source of contemporary sediment discharge (Wohl, 2015). This is the presumed case in some portions of PR where 'legacy sediments' originally eroded from hillslopes during the period of extensive cultivation on the island were originally stored near river margins and are now believed to contribute to a significant portion of watershedscale sediment discharges (Clark and Wilcock, 2000; Larsen and Santiago Román, 2001).

The degree to which terrestrial sediments discharged from watersheds can potentially influence coral reefs depends not only on watershed processes controlling erosion, deposition and discharge but also on the level of connectivity between watersheds and coral reefs (Bainbridge et al., 2018). Throughout the USVI and PR, studies have shown that watersheds can exert an influence on coral environments through the following approaches: (a) spatial distribution of coral species ranked by perceived level of sediment tolerance in relation to distance from watershed outlets (e.g., Acevedo et al., 1989); (b) a proven temporal synchrony between measured seasonal watershed runoff and isotopic signals of dissolved inorganic carbon in coral cores (Moyer and Grottoli, 2011); (c) decreases in net skeletal growth rates determined from coral cores associated with seasonal increases in watershed runoff (Miller and Cruise, 1995); (d) mineralogical fingerprinting of sediment sources (Takesue et al., 2021); and (e) sediment plume mapping using remotely sensed techniques (Hernández et al., 2020). However, none of these studies have demonstrated temporal trends in coral reef conditions in response to changes in sediment discharge corresponding to varying land use, extreme events, or the implementation of erosion mitigation strategies.

Our review of the literature reveals that the science related to sediment dynamics within the marine environment in the northeastern Caribbean lacks the monitoring and modeling capacities implemented in Micronesia and the Great Barrier Reef (e.g., Wolanski et al., 2004). Additionally, the successes in curtailing stresses related to land-based sources of pollution on corals in Micronesia (Richmond et al., 2007) are not easily replicated throughout the northeastern Caribbean. In the islands of Palau, Guam, and Pohnei reductions in pollutant discharges to waters sustaining coral reefs were effective due to the singularity of the stressor and its human cause (i.e., terrigenous sediment discharge associated with accelerated overland flow erosion caused by land clearing) and a unique grassroots governance structure that allowed for widespread implementation of recommendations (i.e., reducing deforestation). In contrast, watersheds in the USVI and PR deliver a wide variety of pollutants to coastal waters including nutrients, fecal pollution, agrochemicals, and heavy metals, among many others (e.g., Bonkosky et al., 2009; Larsen and Webb, 2009; Oliver et al., 2011, 2018; Norat-Ramírez et al., 2019). Additionally, sediments are produced by a variety of sources and are related to numerous activities including road building, agricultural production, and urbanization. Finally, land and coral reef governance in the USVI and PR is complex as management responsibilities fall under a variety of jurisdictions and this makes it difficult to reach a widespread consensus on the actions needed to reduce sediment and other pollutant discharges into coastal waters.

\section{Watershed Assessment: In Practice}

Quantification or estimation of sediment discharge is not an exact science. That is because the processes controlling sediment availability and transport are very complex and variable in time (White, 2005) and this leads to inexact estimates $[ \pm 50 \%$ accuracy in annual sediment yields according to Milliman and Farnsworth (2013)]. Therefore, relying on empirical data to establish statistically significant changes in sediment discharge as a response to land use or climatic forcing is difficult. To add to this challenge, most streams are ungauged, particularly 
in developing countries (e.g., the Insular Caribbean; Lumbroso et al., 2011) where the majority of the world's corals are located (Veron and Phinney, 2006). Therefore, most sediment discharge assessments rely on indirect methods. Most sediment-delivery assessments either have been qualitatively inferred through evaluation of changes in land use or estimated using uncalibrated and unvalidated models (e.g., Burke et al., 2011) and this is particularly true for the Caribbean. Due to the lack of data, it is not possible to rigorously evaluate the performance of the most sophisticated models versus other more simplistic approaches. An in-depth discussion on the pros and cons of the variety of available approaches is beyond the scope of this article. Rather, here we provide a brief critical commentary on how land cover assessments and models have been used for the purpose of estimating watershed sediment discharge to coral-bearing coastal waters.

\section{Assessments of Changes in Land Cover}

Land cover is sometimes used as a proxy for sediment discharge. Land cover assessments characterize what covers the ground (e.g., forest, urbanized and industrial land, cropland, etc.). Characterizations of land cover are generally based on remotesensing methods and are reported in total or proportional area of each cover type. Metrics such as percent land covered by forests or bare ground have been correlated with sediment discharge rates on both small ( $1^{\prime}$ 's km²; Cox et al., 2006; Stock et al., 2011) and medium-to-large watersheds (up to $140,000 \mathrm{~km}^{2}$; e.g., Neil et al., 2002; Shi et al., 2013, 2014). However, even though this approach is more directly related to sediment dynamics than simply relying on changes in human population density (e.g., Carilli et al., 2010) there is no simple universal relationship between land cover (or land cover change) and sediment discharge. Although land cover descriptors by themselves are an imprecise representation of sediment discharge, area-based changes in land cover (e.g., forest cover loss) have been used as substitutes for sediment and other pollutant loads to coral reefs at many locations (e.g., Oliver et al., 2011, 2014; Carlson et al., 2019). The extent of unsurfaced road networks also has been used as a proxy (e.g., Craik and Dutton, 1987; Brooks et al., 2007). Land cover change (i.e., amount of land converted from one type to another like for example from forest to cropland), in combination with linear distance from watershed outlet to coral-reef areas, have been used as representations of sediment exposure (e.g., Lirman and Fong, 2007). Although convenient due to the relatively easy accessibility of land cover data and qualitatively useful, relying purely on land cover as an indicator for sediment-related stress has the following limitations.

1. The approach lacks an erosion-specific metric (e.g., $\mathrm{Mg}$ year $^{-1}$ ). Therefore, it cannot quantitatively assess the effect of particular land use transitions (e.g., deforestation for agriculture vs. for urbanization) on sediment discharge. Furthermore, it ignores where land cover changes occur with regard to factors known to affect erosion (e.g., soil type, slope, rain characteristics, etc.; Renard et al., 1997). Finally, it does not provide an evaluation of the net impact of complex yet common land use transitions, such as concurrent reforestation, cropland abandonment, and urbanization on sediment yields (e.g., Ramos-Scharrón et al., 2015).

2. The approach is unable to account for the relative contributions of individual sediment sources to sediment discharge. Prioritizing specific sediment sources based on their net contribution can improve the cost-effectiveness of management strategies (Beher et al., 2016) but using land cover by itself will not allow land managers to prioritize erosion control actions. In addition, relying solely on land cover fails to consider distinct erosion and sediment connectivity potentials which are presently considered essential in watershed-sediment assessments (Bracken et al., 2015).

3. Relying on specific land cover types as proxies for sediment delivery tends toward generic policy recommendations, like reforestation (e.g., Suárez-Castro et al., 2021), with questionable levels of success (e.g., Basher, 2013; RamosScharrón and Figueroa-Sánchez, 2017). On small- to medium-sized watersheds like those draining the USVI and $\mathrm{PR}$, relatively small sources are responsible for a sizable portion of the sediment yield (e.g., Ramos-Scharrón and MacDonald, 2007b; Stock et al., 2014; Labrière et al., 2015; Carlson et al., 2019), and depending on previous uses, forested lands can produce similar amounts of sediment as those that are actively used (Ramos-Scharrón et al., 2021). Therefore, land cover-based assessments may fail to consider sediment sources such as small quarries (e.g., Messina and Biggs, 2016), landslides (Larsen, 2012) and unpaved roads (e.g., MacDonald et al., 1997) that can disproportionately affect sediment discharge.

Two examples from the northeastern Caribbean emphasize the unreliability of land cover as a sediment delivery proxy. Analyses of sediment cores have indicated a 10 -fold and a 2fold increase in terrestrial sediment accumulation rates starting in the mid-20th century for Coral Bay, St. John-USVI (Brooks et al., 2015) and for southwest PR (Ryan et al., 2008), respectively. For most of St. John, the 20th century represents a period of net reforestation following the abandonment of plantation style agriculture in the late 1800s (Tyson, 1987), while the 1950s coincide with the first time roads were built on the island using heavy earth-moving machinery (MacDonald et al., 1997). Similarly, in PR the 1950s were the initial stages of a transitional period from an agrarian to an industrial economy which resulted in a reforestation rate that was unparalleled throughout the world (Rudel et al., 2000), but one that was combined with the growth of urban centers mostly near the coastlines (Hernández-Delgado et al., 2012). These two examples demonstrate the unreliability of land cover as a proxy for marine sediment deposition and thus coral reef sediment exposure levels.

\section{Watershed Models}

Regardless of its sophistication, no watershed model can guarantee a high degree of accuracy. Calibration and validation are essential components of watershed modeling practice (Moriasi et al., 2007). However, even if validated, models can 
still misrepresent actual sediment dynamics (Smith et al., 2011). Watershed models that are used to estimate sediment discharge are conceptualized in some form of the sediment budget framework in that they apply the principle of mass conservation (Equation 2) where erosion is allocated to either "storage" or "sediment discharge" (e.g., Bartley et al., 2007; Wenger et al., 2020). In essence, sediment budgeting analyses can lead to targeted mitigation strategies. For example, the Reef Plan for the Great Barrier Reef in Australia recommends controlling erosion from streambanks and grazing lands as these are understood to produce large quantities of sediment that are efficiently discharged by the contributing watersheds (Kroon et al., 2016). A similar response is occurring in the Insular Caribbean where studies have identified unpaved roads as key sources of sediment (Ramos-Scharrón et al., 2012a; Ramos-Scharrón and FigueroaSánchez, 2017). This has led to the inclusion of unpaved roads as a target for watershed mitigation strategies in the USVI and PR (NOAA, 2016) (see Case Studies). Identification of these sources as key elements in the sediment budget of these watersheds has relied on modeling results as well as field and remotely-sensed identification of erosion processes and sediment connectivity pathways.

Here, we briefly summarize some of the challenges in the use of models, specifically those used to assess watershed discharges to coral reef areas.

1) Sediment models must incorporate key erosion and depositional processes (de Vente et al., 2013) to avoid misguided management recommendations (Parsons, 2012). For example, if streambank erosion is believed to be an important process within a watershed and the chosen model lacks the capacity to incorporate it into the analyses, management strategies relying on the model will fail to address a key sediment source. As a result, the benefits of prescribed actions will be limited. At the very least, sediment-budget valuations must include field assessments and aerial image interpretation by trained personnel (Reid and Dunne, 1996). While photo interpretation allows us to characterize large areas of interest (e.g., cultivated plots), field-based evaluations can characterize processes that might be missed by remote sensing techniques (e.g., gullying below road drains; Koci et al., 2020).

2) Models can be biased toward erosion by rain-driven overland flow and some watershed modeling platforms only contain algorithms that address this type of erosion. In addition, many models rely on the Revised Universal Soil Loss Equation (RUSLE; Renard et al., 1997; Nearing et al., 2005) which can over-predict erosion rates by a factor of 45 (e.g., Brooks et al., 2014). Rill and gully erosion are only included where field data are available (e.g., McKergow et al., 2005). Models such as the Soil and Water Assessment Tool (SWAT) (Arnold et al., 2012) provide options to include streambank erosion but, to our knowledge, their accuracy has not been verified when applied to assessments of sediment delivery from watersheds to coral reefs. Estimation of streambank erosion is difficult because of the limited studies and unknown error propagation when
BOX 1 | Sediment connectivity - The challenge.

The portion of the sediment eroded from each source that contributes to sediment discharge depends on its erosion rate but also on its potential to reach the watershed outlet. Much work along these lines has recently coalesced within the concept of "sediment connectivity" (Fryirs, 2013) yet no approach can fully encompass all types of sediment sources and delivery scenarios. That is because the delivery of sediment from a source to a watershed outlet is controlled by a variety of factors including the type of erosion process (e.g., landslide or erosion by overland flow), rainstorm size and intensity, sediment size, and landscape characteristics such as soil infiltration and the presence of sediment trapping obstacles, the location and upslope extent of the stream network, sediment transport capacity of the stream networks, and landscape slope, among others (Heckman et al., 2018). The degree to which sediment from a given source (e.g., an unpaved road segment, a plot of agricultural land, or a quarry) can reach a watershed outlet is referred to as its degree of sediment connectivity but limited empirical data have documented this transfer of sediment across the landscape.

Quantification of erosion, sediment transport within watersheds, and sediment discharge are rarely conducted simultaneously as such types of monitoring efforts are logistically challenging (Turnbull et al., 2018).

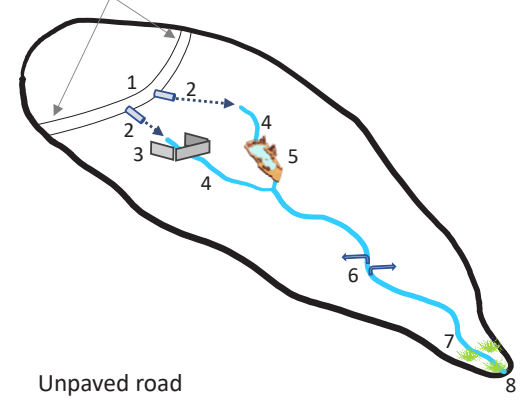

In the scenario shown here, a mostly impermeable unpaved road erodes by the action of overland flow and its sediment is delivered to the surrounding landscape by two culverts. The amount of road sediment (1) that reaches the watershed outlet (8) is controlled by erosion occurring on the road, but also by the interaction of road runoff and sediment with their downslope flow pathways (2-7). These pathways could be of many different types including: (2-3) the portion of the landscape between the road and the headwater streams which might or might not be interrupted by sediment control structures (e.g., silt fences, buffer strips, etc.); (4-5) sediment transport along headwater streams which might or might not be disrupted by check dams or detention ponds; (6) transport along lowland rivers which depends on the river's transport capacity, the presence of dams, and the river's interactions with sinks such as floodplains; and (7) the trapping efficiency of any existing coastal sediment sinks like estuaries or salt ponds.

empirical data are extrapolated to the watershed scale (Couper, 2004). The inclusion of landslides largely remains a research-level exercise, because of the detail required to adequately characterize connectivity with the fluvial network (Li et al., 2016) and the stochastic nature of sediment releases by landsliding (i.e., controlled by the probability of an event occurring like for example a significant rainstorm; Korup et al., 2010).

3) Models can leave out of the analysis important sources of sediment due to the spatial scale at which erosion processes are quantified. For example, application of the SWAT model to areas in PR containing coffee farms inevitably homogenize the landscape (e.g., Yuan et al., 2016). In these settings, SWAT subdivides watersheds into landscape units that typically lump various farms with their surrounding 
forested areas and for which only one combination of slope, soil, and land cover values is used to calculate a single average erosion rate for the landscape unit. This approach could miss important components of the landscape, like the unpaved roads, which are responsible for $>90 \%$ of all surface erosion produced within farms (Ramos-Scharrón and Thomaz, 2017). A promising alternative has been employed in Australia where modeling has been performed at two spatial scales. One is zoomed in at the farmscale and relies on empirically-derived models, while the other provides analyses at the larger sub-watershed scale (Carroll et al., 2012). This approach simultaneously informs both farm- and watershed-level mitigation and monitoring (Beher et al., 2016).

4) Models tend to generate results that are more sensitive to land use changes or mitigation strategies than those documentable with empirical data. This is in part because many watersheds are not very sensitive, that is, changes in erosion do not readily translate to higher sediment discharges due to the effects of storage sinks (i.e., a relatively large $\Delta$ Storage component in Equation 2; Fryirs et al., 2007). In general, the larger the watershed the less sensitive its sediment discharge to changes in erosion. Most models used to estimate watershed-scale sediment discharge are overly dependent on erosion algorithms that fail to properly account for sediment retention (Parsons et al., 2006). Even when monitored, sediment discharge is quite variable and hard to measure accurately, making it difficult to empirically prove the statistical significance of any changes (Morehead et al., 2003). It is important to note, that what little we presume to know about the effects of land cover changes or the efficiency of mitigation strategies on sediment discharge to coral reefs is largely based on modeling and not on empirical data (Kroon et al., 2016).

5) Calibration and validation are crucial components of any modeling effort. However, sediment monitoring in rivers is costly, labor intensive, and logistically challenging. To ensure model accuracy and to enhance our confidence in them, data are needed to calibrate and validate models that consider the combined effects of climate, topography, and land use in the types of watersheds that drain toward coral-reef ecosystems.

6) Models based on a Bayesian approach in essence rely on a probabilistic network framework (i.e., cause and effect relationships) to explicitly incorporate the uncertainties of model input factors and processes to make a prediction. Among other applications, Bayesian modeling approaches have been used as a tool to improve sediment discharge estimates based on empirically-collected discharge and suspended sediment data (Pagendam et al., 2013) and to assess the consequences of watershed actions (e.g., application of erosion control methods) on specific sets of outcomes (e.g., sediment discharge or ecosystem services of interest; e.g., Carriger et al., 2019). Although they provide a significant benefit to assess very complex relationships, Bayesian watershed management modeling attempts rely on the types of watershed models described above and therefore suffer from the same limitations. A Bayesian approach will not compensate for any failures of the sediment budgeting models to properly address sediment dynamics. For example, Bayesian modeling applications in a watershed in western PR relied on a model that only accounted for sediment produced by surface erosion on cultivated land (Bousquin et al., 2014). Results of such applications suggested that the best approach to curb sediment stress to coral reefs was to convert coffee farming from sun to shade-grown (Bradley et al., 2016). However, this erosion model did not account for sediment contributions from unpaved roads and landsliding, which have been shown to dominate the sediment budget of that particular watershed (Ramos-Scharrón and FigueroaSánchez, 2017; Ramos-Scharrón et al., 2021).

\section{CASE STUDIES FROM THE NORTHEASTERN CARIBBEAN}

\section{U.S. Virgin Islands and Culebra-Puerto Rico}

The USVI and the island of Culebra-PR are drained by ephemeral streams within micro-watersheds ranging in size from a few hectares to about $10 \mathrm{~km}^{2}$ (Ramos-Scharrón and LaFevor, 2016). Even though land use at both locations is legally restricted by the intended enforcement of the Coastal Zone Management Act and more than thirty protected areas, terrestrial sediment is still considered an important coral-reef stressor (Rogers et al., 2008, Commonwealth of PR and NOAA, 2010). Progression in how watershed sediment discharge to coral reefs has been addressed in the USVI and Culebra follows the same general timeline for most of the world. The earliest evidence of sediment-related concerns with respect to coral reefs in the USVI dates to the late 1970s, when water-turbidity monitoring was initiated and relatively high values were detected at some locations (US-EPA, 1983). Anecdotal evidence from the 1980s includes the documentation of noticeable sediment entering coral-bearing waters adjacent to recently developed watersheds (Beets et al., 1986; Rogers and Teytaud, 1988) and the tendency for coral-colonized substrates to be located away from stream outlets and large watersheds (Hubbard, 1986; Hubbard et al., 1987). Anecdotal evidence in Culebra was first documented in the early 1990s (Collazo et al., 1992; Hernández-Delgado, 1992) and formally evaluated through modeling (Ramos-Scharrón et al., 2012a) and, much later, monitoring (Otaño-Cruz et al., 2017; Gómez-Andújar and Hernández-Delgado, 2020).

Sediment-budget studies combining various forms of empirical data, field-based and remotely-sensed reconnaissance of erosion processes by trained personnel, and watershed modeling led to the identification of the unpaved road network as the main source of sediment on many of the islands' watersheds (Figures 2a-c; Anderson and MacDonald, 1998). Unpaved roads stand out as sediment contributors due to the combination of: (a) erosion rates that are up to four orders of magnitude greater than natural rates (Ramos-Scharrón and MacDonald, 2005; 
McLaughlin, 2019); (b) the relatively minor contribution from other sediment sources due to a low degree of development and lack of widespread agricultural activity; and (c) the absence of widespread landsliding (MacDonald et al., 1997). Runoff and sediment delivery in these ephemeral-stream settings naturally occur only a handful of times per year (Larson et al., 2015), but unpaved roads can potentially induce a tenfold increase in the magnitude and frequency of sediment delivery to coastal waters (Ramos-Scharrón and LaFevor, 2018). Suspended sediment concentrations of runoff discharged from roaded watersheds are in the 100 s to $1,000 \mathrm{mg} \mathrm{L}^{-1}$ range while those from undisturbed watersheds are only in the 10 s to less than $100 \mathrm{mg} \mathrm{L}^{-1}$ (RamosScharrón, 2004). Studies from a variety of terrestrial and marine perspectives agree that sediment loads into coral reefs are highly dependent on the density of unpaved roads (Nemeth and Nowlis, 2001; Brooks et al., 2007; Ramos-Scharrón and MacDonald, 2007a; Gray et al., 2008; Otaño-Cruz et al., 2017) and that sediment-related impacts on adjacent coral reefs are strongly dependent on the distance between them and updrift watershed outlets (Smith et al., 2008; Otaño-Cruz et al., 2019).

The small size and steepness of watersheds in the USVI and Culebra, in combination with the low erosion rates from undisturbed areas (2-8 $\mathrm{Mg} \mathrm{km}^{-2}$ year ${ }^{-1}$ ) and the potential for land disturbance to increase erosion by several orders of magnitude set the stage for drastic changes in sediment discharges even with relatively limited development (RamosScharrón and MacDonald, 2007b). The degree to which increases in hillslope erosion may lead to greater sediment discharge is referred to as "sensitivity" (Fryirs et al., 2007). This is a function of connectivity (see Box 1) and is dependent on the proximity of sediment sources to the stream network, stream gradient, and the effectiveness of sediment-storage elements (e.g., salt ponds), among other factors. Where coastal wetlands that are capable of retaining eroded sediment are absent, the proportion of sediment mobilized within USVI and Culebra watersheds that is delivered to coastal waters is expected to be quite high ( $\sim 75 \%$; RamosScharrón and MacDonald, 2007a; Ramos-Scharrón, 2021).

The 69-ha, short ( $\sim 0.8 \mathrm{~km}$ from ridgeline to coastline) and steep (average slope of $25^{\circ}$ ) Hawksnest Bay watershed in St. John lies mostly within Virgin Islands National Park boundaries and is, therefore, largely undisturbed. However, development has occurred and has led to varying degrees of soil exposure. The main source of sediment up until the 1970s was a limited network of unpaved roads that occupied ca. 3.5\% of the watershed. Application of the locally and empirically derived STJ-EROS model (Ramos-Scharrón and MacDonald, 2007a) suggests that the unpaved road network in the 1970s likely led to sediment yields $\sim 90$ times above background rates (Figure 3). Paving of a significant stretch of a road in the late 1970s reduced the proportion of watershed with exposed soils by half and that may have reduced sediment discharge into the bay by about a third. Land clearing associated with the construction of a medical clinic that began in October of 1980 (Hubbard et al., 1987) increased the proportion of exposed soil to $4.6 \%$ and sediment discharge to $\sim 130$ times above background, which is likely the highest the watershed has ever experienced. Construction of this clinic coincided with the occurrence of one of the island's highest recorded daily rainfall totals (18 April 1983; total: 381$483 \mathrm{~mm}$ and max intensities $132-152 \mathrm{~mm} \mathrm{~h}^{-1}$ at Caneel Bay and Trunk Bay, respectively: Curtis, 1985; Boulon. personal communication, 13 March 2021). During this brief event, about $215 \mathrm{Mg}$ of sediment are estimated to have reached the bay in a single day ( $\sim 85 \%$ from the construction site). This pulse of sediment may have been a cause of short-lived decreases in the growth rate of the dominant coral species Orbicella annularis (formerly Montastraea annularis) documented in Hawksnest Bay (Hubbard et al., 1987). The sediment pulse may also have been responsible for the mortality of Acropora palmata colonies in eastern Hawksnest closest to the watershed outlet (Beets et al., 1986). However, even in this situation where a significant pulse of sediment was evidently delivered directly to coral reefs, there is a lack of direct evidence of sediments being responsible for coral losses.

Currently, the estimated sediment yield is $\sim 3,000 \%$ above undisturbed conditions even though only portions of the developed areas remain unvegetated and the limited new-road segments have been mostly paved. Our estimates indicate that sediment delivery from this watershed can increase 25 -fold over background for every $1 \%$ increase in land area converted to bare soil. This highlights the sensitivity of these small and steep watersheds to even minor levels of disturbance. It also points at the need to limit erosion by quickly introducing vegetation, paving existing roads and enhancing sedimentstorage capacity with detention ponds in order to protect nearshore coral reefs from sediments resulting from new or already existing development.

Anecdotal evidence and scientific studies relying on modeling and both field-based and remotely-sensed evidence within the USVI and Culebra (e.g., MacDonald et al., 1997) have helped to develop watershed-management strategies that target decreasing erosion from unpaved roads and reducing connectivity (Commonwealth of PR and NOAA, 2010; The Territory of USVI and NOAA, 2010; Reed, 2012; HWG and PDC, 2017). Strategies have included cutting erosion rates along unpaved roads by a third through road-drainage improvements (Ramos-Scharrón, 2012), retaining sediment in detention ponds (Ramos-Scharrón et al., 2012b; Figure 2d), and redirecting runoff to hillsides and ephemeral streambeds to reduce the frequency of sediment delivery to coastal waters, among others (Reed, 2012; Ramos-Scharrón and LaFevor, 2018).

\section{Río Loco-Guánica Bay, Puerto Rico}

Selecting the Río Loco-Guánica Bay (RLGB) watershed-marine system as a coral reef conservation priority for PR was partly due to the degraded state of corals in the vicinity of Guánica Bay (Figure 4; Bauer et al., 2013) and the alarming levels of chemical pollutants in its sediments (Whitall et al., 2014). Another likely driver for its priority designation was the perception that sediments and pollutants delivered to the bay could be carried $\sim 10-20 \mathrm{~km}$ westward by longshore currents to the coral reef ecosystems of the La Parguera Nature Reserve (Otero and Carbery, 2005; Ryan-Mishkin et al., 2009).

As a waterway, Río Loco is one of the most manipulated on the island because it serves as the axis for PR's Southwest 

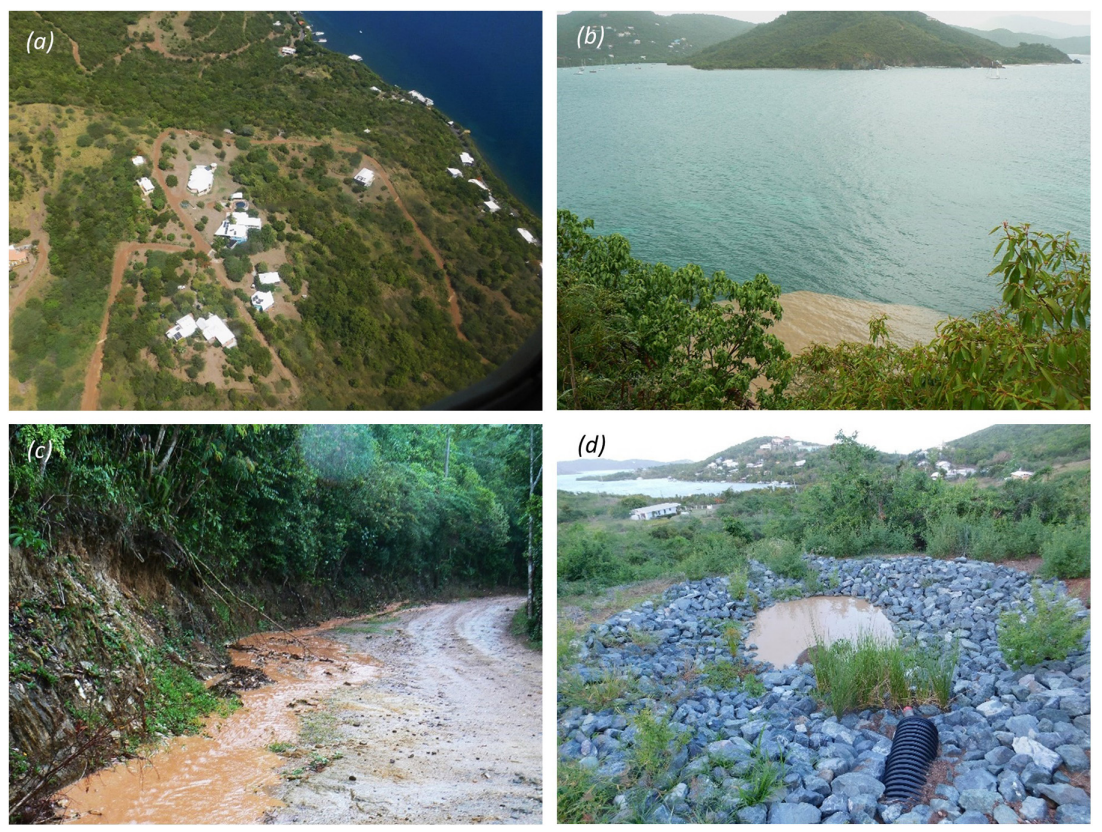

FIGURE 2 | (a) Aerial view of the land-development style that typifies the USVI and Culebra (photo from Punta Aloe, Culebra-PR); (b) suspended sediment derived from unpaved roads after a brief rain shower in Coral Bay, St. John-USVI; (c) road runoff and erosion in Coral Bay; (d) a small sediment-retention pond in Culebra-PR.

Water Project. The project consists of a complex system of two hydropower plants and five water reservoirs connected by tunnels and irrigation canals that facilitate inter-basin transfers (Ortiz-Zayas and Terrasa-Soler, 2001). Even though the system expanded Rio Loco's effective catchment area by $580 \%$ (from 60 to $\sim 345 \mathrm{~km}^{2}$ ), it prevents the delivery of baseflow runoff to the bay as most water is consumed or stored before it reaches the ocean. The paucity of runoff along the lower reaches of the watershed has hindered the collection of suspended- sediment data to properly quantify sediment yields into Guánica Bay (Korman et al., 2020). However, sediment accumulation rates on two of the main reservoirs of this system (Lago Loco and Lago Lucchetti) indicate yield rates ranging from 1,775 to $3,170 \mathrm{Mg}$ $\mathrm{km}^{-2}$ year $^{-1}$ (Soler-López, 2002; Gómez-Fragoso, 2016) and they represent two of the highest values for PR (island average $\sim 1,080 \mathrm{Mg} \mathrm{km}^{-2}$ year $^{-1}$; Larsen and Webb, 2009). The high sediment yields confirm that the combination of high annual rainfall rates $\left(\sim 2,000 \mathrm{~mm}\right.$ year $\left.^{-1}\right)$, steep topography, and land disturbance associated with sun-grown coffee farming in the watershed uplands leads to high erosion and sediment discharge rates (Yuan et al., 2016; Ramos-Scharrón et al., 2021).

Designation of RLGB as a priority conservation area led to the development of a watershed-management plan in 2008 that relied on watershed modeling, local knowledge and field-based assessments to make restoration recommendations (CWP, 2008). The plan endorsed the stabilization of streambanks along the lower reaches of the Río Loco and mitigating soil erosion in coffee farms through the conversion of coffee-farming practices from sun-grown to shaded-coffee (Sturm et al., 2012). However, subsequent empirical evidence has shown that the dense network of unsurfaced access roads in the farmed acreage is a dominant source of the sediment produced by coffee farms (RamosScharrón and Thomaz, 2017; Figueroa-Sánchez, 2019). The watershed plan has adapted to this new evidence by focusing on unpaved roads (Viqueira-Ríos, 2018) and by promoting research that could evaluate the performance of mitigation efforts such as road-surface graveling (Ramos-Scharrón and FigueroaSánchez, 2017), and road fillslope and cutslope stabilization (Figueroa-Sánchez et al., 2015; Ramos-Scharrón et al., 2022). In 2017, rainfall associated with Hurricane María triggered several thousand landslides that clustered in steep terrain currently or previously used for agricultural purposes within Río Loco's interconnected watershed (Ramos-Scharrón et al., 2020). Estimates of the amount of sediment mobilized by landslides during Hurricane María indicate that landsliding is more important than surface erosion within RLGB (RamosScharrón et al., 2021). In addition, recent geochemical evidence has proven a connection between sediments being delivered by watersheds draining to the coastline $\sim 15 \mathrm{~km}$ east from coral reefs off Guánica Bay (Takesue et al., 2021). This sediment connectivity had been recognized only anecdotally in the past (Acevedo et al., 1989). These recent findings serve as a new challenge to be addressed by future versions of the Guánica Bay management plan.

Designation of RLGB attracted expertise and funding to help mitigate watershed problems affecting Guánica Bay and other connected coral-reef systems (Carriger et al., 2013). Although watershed efforts still need to be substantially propagated to generate tangible results, the plan has identified adaptive capacities to allow mitigation strategies to adapt to newly emerging evidence. The plan has also resulted in ecosystem-service benefits beyond coral-reef protection that 

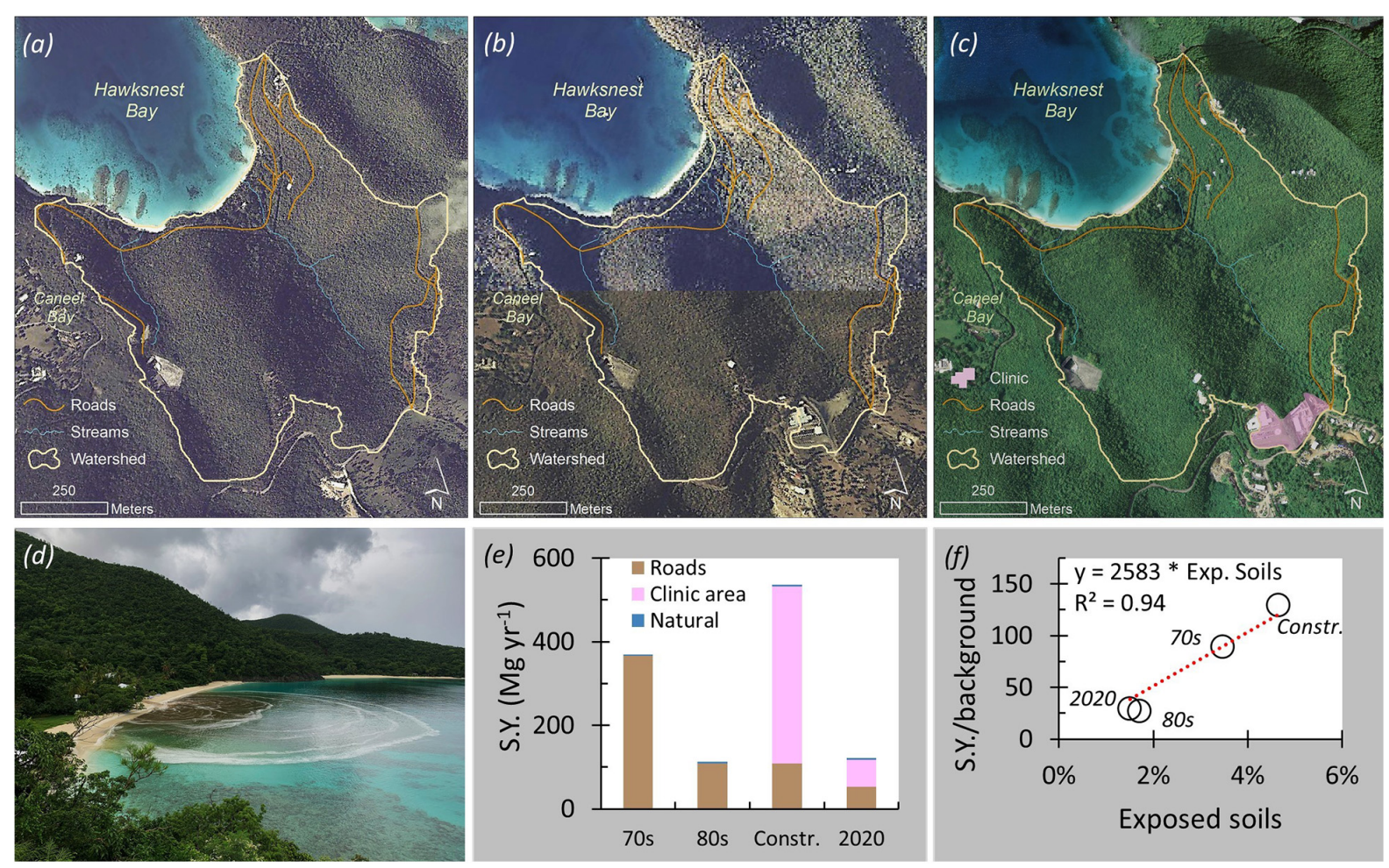

FIGURE 3 | (a-c) Aerial images showing roads in the Hawknest Bay watershed of St. John (1974, 1983, and 2006, respectively); (d) runoff and sediment entering Hawksnest Bay following a 30 mm rainstorm in 16 October 2020; (e) STJ-EROS sediment-delivery estimates for conditions in the 1970s, the 1980s both prior to and during construction of the clinic, and in 2020; (f) estimated relationship between the proportion of the watershed with exposed soils and the ratio of sediment yield to background delivery levels. [STJ-EROS estimates erosion rates from empirically-derived equations that rely on slope and annual precipitation. Road slopes are based on field surveys; slopes for the clinic area were determined from a 1-m resolution digital elevation model for 2018. Application to the Hawksnest Bay watershed presumed a sediment-delivery ratio of 0.75 (Ramos-Scharrón and MacDonald, 2007a)].

are of concern to the variety of stakeholders in the area and are likely to promote a long-term commitment to the management plan (Borkhataria et al., 2012; Smith et al., 2017).

\section{RELEVANCE OF A CHANGING CLIMATE TO TERRESTRIAL SEDIMENT STRESS}

Climate change in part involves alterations to rainfall patterns, which are a key control on erosion and watershed sediment delivery. Precipitation patterns will most likely change, with a combination of more extreme droughts and rainstorms in many areas (Karl et al., 2008). A key expected outcome is for major storms to become less frequent but more intense in the tropics (Knutson et al., 2010). Distribution of rain throughout the year could also change, which for the Caribbean would likely involve a further decrease in rainfall in the summer dry period interrupted by more intense extreme events mostly in the form of major hurricanes (Taylor et al., 2012). Effects on coral reefs could occur through changes in the amount of land erosion by overland flow, landslides and streambank erosion, and/or alterations in the sediment transport and storage capacities of watersheds (Coulthard et al., 2012). Hurricanes generating large quantities of rainfall can induce large releases of sediment by landsliding and prolonged high discharge rates that can affect coastal water quality for extended periods, as was observed in PR following Hurricane María in 2017 (Miller et al., 2019; Hernández et al., 2020; Ramos-Scharrón et al., 2021).

Even though we lack an overall understanding of the relative contribution of sediment stress and global factors in driving coral loss and reef degradation (Bruno and Valdivia, 2016), in the case of increases in sediment delivery, effects can be inextricably linked to local human activities that can be reduced or controlled (MacNeil et al., 2019). This is in contrast with thermal stress and its concomitant effects on corals that managers cannot control. Exposure to sediment is a local stressor, but one that could be affected by anticipated increases in precipitation associated with a changing climate (Knutson et al., 2010; Coulthard et al., 2012). As a result, it is possible for local stressors to become more critical than regional and global stressors in some locations (Kennedy et al., 2013). For example, Maina et al. (2013) used models to project that continued future clearing of forests in Madagascar is likely to outweigh any reductions in sediment discharge associated with an expected climate change driven decline in rainfall. In summary, with limited 

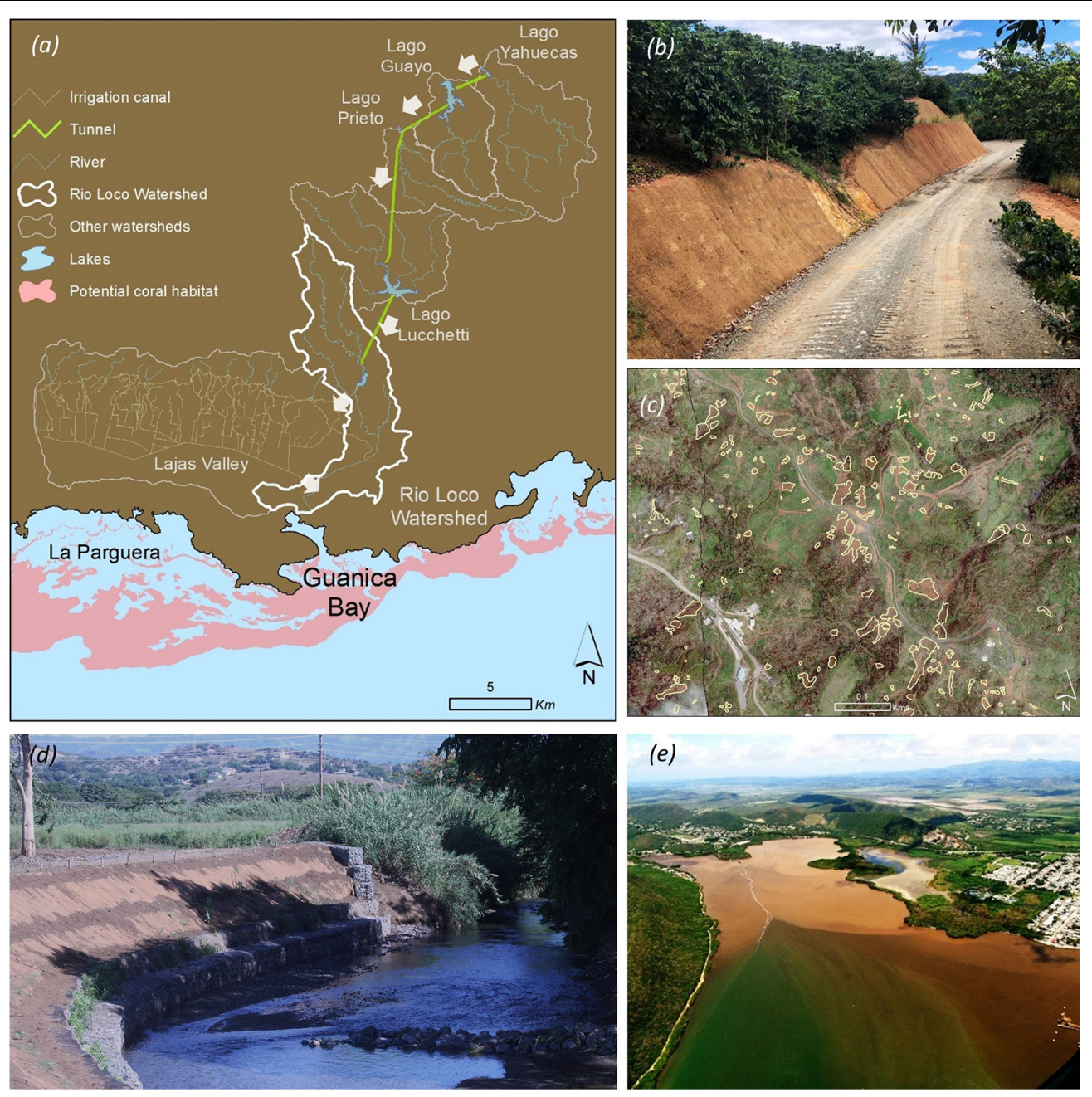

FIGURE 4 | (a) Map of the Río Loco and Guánica Bay system including all linked watersheds, lakes (blue), irrigation canals, tunnels, and submerged areas (pink) prone for coral reef growth [arrows indicate the direction of inter-basin water and sediment transfers]; (b) part of the road-erosion-control work being conducted within coffee farms in the Lucchetti Watershed by Protectores de Cuencas Inc. (PDC) including the use of geotextile to stabilize cutslopes, road grading, and surface graveling; (c) some of the more than 1,700 shallow landslides in the upper reaches of the Lago Lucchetti Watershed caused by Hurricane María (borders of landslides are highlighted in orange); (d) streambank stabilization work conducted by the Natural Resources Conservation Service (NRCS) in the Las Latas area of the lower Río Loco watershed (photo by L.H. Rosado, NRCS); (e) sediment entering Guánica Bay (photo by PDC).

exceptions, all evidence points to a continued decline in the amount of living coral worldwide at local and global scales. Functional collapse of coral reefs could be imminent (Kennedy et al., 2013). Over time, corals that successfully adapt to the higher temperatures and lower $\mathrm{pH}$ could still be killed by a local stressor such as sediment delivery from a watershed, dredging or filling of a bay, or by increased pollution.

\section{CONCLUSION}

Our understanding of the effects of sediments on corals and coral reefs has significantly advanced over the past several decades. However, we still lack definitive long-term studies quantifying changes in reef structure and function with increased sediment input and showing recovery of reefs following exposure to sediments and subsequent implementation of management actions. Evaluating the contribution of sediment exposure to coral reef degradation is challenging, particularly in light of regional and global factors such as warming sea water temperatures, disease outbreaks, and increased intensity of cyclones. In addition, the future is dynamic and projected to involve major changes in many key environmental factors.

A reliable, all-purpose approach to identifying or quantifying sediment sources in any watershed on Earth does not exist. However, research conducted in the Caribbean and elsewhere on erosion and watershed sediment discharge to coral reefs since the 1990s has resulted in several important recommendations for both management and research. In terms of sediment sources, studies have shown that landslides may be key contributors in 
steep, wet tropical terrain and that in many cases sediment sources with a small areal footprint, such as unpaved roads and quarries, contribute a disproportionally large amount of the sediment discharged from watersheds. Models can aid in the identification of priority targets but, to be effective management tools, these must incorporate the key erosion processes present in the watershed and must be validated by empirical data at least in selected watersheds. Another key result of recent work is that not only the net amount of sediment eroded is important in defining priority targets for erosion mitigation but also the degree of connectivity of the sediment sources with the streams, the watershed outlet, and the coral reefs themselves. The most effective mitigation strategies typically focus on the key sediment sources through a combination of methods that provide an adequate management of overland flow, protect erodible surfaces with vegetation or geotextiles, and reduce connectivity with traps or sediment retention basins. Our understanding of watershed sediment discharge effects on coral reefs can be improved through studies that combine reliable quantitative methods to estimate sediment delivery with oceanographic and coral reef monitoring efforts to address sediment effects with biologicallysignificant and temporally-meaningful metrics.

\section{REFERENCES}

Acevedo, R., Morelock, J., and Olivieri, R. A. (1989). Modification of coral reef zonation by terrigenous sediment stress. Palaios 4, 92-100. doi: 10.2307/ 3514736

Adame, M. F., Neil, D., Wright, S. F., and Lovelock, C. E. (2010). Sedimentation within and among mangrove forests along a gradient of geomorphological settings. Estuar. Coast. Shelf Sci. 86, 21-30. doi: 10.1016/j.ecss.2009.10.013

Alvarez-Filip, L., Estrada-Saldívar, N., Pérez-Cervantes, E., Molina-Hernández, A., and González-Barrios, F. J. (2019). A rapid spread of the stony coral tissue loss disease outbreak in the Mexican Caribbean. PeerJ 7:e8069.

Anderson, D. M., and MacDonald, L. H. (1998). Modelling road surface sediment production using a vector geographic information system. Earth Surf. Process. Landforms 23, 95-107. doi: 10.1002/(sici)1096-9837(199802)23:2<95:: aid-esp849>3.0.co;2-1

Anthony, K. R. N., and Larcombe, P. (2000). "Coral reefs in turbid waters: sediment-induced stresses in corals and likely mechanisms of adaptation," in In Proceedings of the 9th International Coral Reef Symposium, Bali, 239-244.

Arias-González, J. E., Fung, T., Seymour, R. M., Garza-Pérez, J. R., AcostaGonzález, G., Bozec, Y. M., et al. (2017). A coral-algal phase shift in Mesoamerica not driven by changes in herbivorous fish abundance. PLoS One 12:e0174855. doi: 10.1371/journal.pone.0174855

Arnold, J. G., Moriasi, D. N., Gassman, P. W., Abbaspour, K. C., White, M. J., Srinivasan, R., et al. (2012). SWAT: model use, calibration, and validation. Trans. ASABE 55, 1491-1508.

Aronson, R. B., Hilbun, N. L., Bianchi, T. S., Filley, T. R., and Mckee, B. A. (2014). Land use, water quality, and the history of coral assemblages at Bocas del Toro, Panamá. Mar. Ecol. Prog. Ser. 504, 159-170. doi: 10.3354/meps 10765

Bahr, K. D., Jokiel, P. L., and Toonen, R. J. (2015). The unnatural history of Kanne'ohe Bay: coral reef resilience in the face of centuries of anthropogenic impacts. PeerJ 3:e950. doi: 10.7717/peerj.950

Bainbridge, Z., Lewis, S., Bartley, R., Fabricius, K., Collier, C., Waterhouse, J., et al. (2018). Fine sediment and particulate organic matter: a review and case study on ridge-to-reef transport, transformations, fates, and impacts on marine ecosystems. Mar. Pollut. Bull. 135, 1205-1220. doi: 10.1016/j.marpolbul.2018. 08.002

Ballantine, D. L., Appeldoorn, R. S., Yoshioka, P., Weil, E., Armstrong, R., Garcia, J. R., et al. (2008). "Biology and ecology of Puerto Rican coral reefs," in Coral

\section{AUTHOR CONTRIBUTIONS}

Both authors listed have made a substantial, direct, and intellectual contribution to the work, and approved it for publication.

\section{FUNDING}

Funding for salary (CR) and publication costs were provided by the U.S. Geological Survey's Wetland and Aquatic Research Center.

\section{ACKNOWLEDGMENTS}

Our sincere thanks to Dennis K. Hubbard (Oberlin University) and Lisa Vandiver (NOAA Restoration Center) for thoughtful, comprehensive and encouraging reviews of an early draft of this manuscript, and to two reviewers who made very constructive suggestions that helped us to significantly improve the manuscript.

Reefs of the USA, eds B. M. Riegl and R. E. Dodge (Dordrecht: Springer), 375-406. doi: 10.1371/journal.pone.0096028

Bartley, R., Hawdon, A., Post, D. A., and Roth, C. H. (2007). A sediment budget for a grazed semi-arid catchment in the Burdekin basin, Australia. Geomorphology 87, 302-321. doi: 10.1016/j.geomorph.2006.10.001

Bartley, R., Thompson, C., Croke, J., Pietsch, T., Baker, B., Hughes, K., et al. (2018). Insights into the history and timing of post-European land use disturbance on sedimentation rates in catchments draining to the Great Barrier Reef. Mar. Pollut. Bull. 131, 530-546. doi: 10.1016/j.marpolbul.2018.04.070

Basher, L. R. (2013). "Erosion processes and their control in New Zealand," in Ecosystem Services in New Zealand-Conditions and Trends, ed. J. Dymond (Lincoln: Manaaki Whenua Press), 363-374.

Bauer, L., Edwards, K., and Caldow, C. (2013). "Fish communities and associated benthic habitats in the Guánica Bay Region of Southwestern Puerto Rico," in Baseline Assessment of Guánica Bay, Puerto Rico in Support of Watershed Restoration, eds D. Whitall, L. J. Bauer, C. Sherman, K. Edwards, A. Mason, T. Pait, et al. (Silver Spring, MD: NOAA), 5-62.

Beets, J., Lewand, L., and Zullo, E. S. (1986). Marine Community Descriptions and Maps of Bays Within the Virgin Islands National Park/Biosphere Reserve, Biosphere Reserve Research Report No. 2. St. Thomas: Island Resources Foundation.

Bégin, C., Brooks, G., Larson, R. A., Dragicevic, S., Ramos-Scharrón, C. E., and Côte, I. M. (2014). Increased sediment loads over coral reefs in Saint Lucia in relation to land use change in contributing watersheds. Ocean Coast. Manag. 95, 35-45.

Beher, J., Possingham, H. P., Hoobin, S., Dougall, C., and Klein, C. (2016). Prioritising catchment management projects to improve marine water quality. Environ. Sci. Policy 59, 35-43. doi: 10.1016/j.envsci.2016.0 2.005

Birrell, C. L., McCook, L. J., and Willis, B. L. (2005). Effects of algal turfs and sediment on coral settlement. Mar. Pollut. Bull. 51, 408-414. doi: 10.1016/j. marpolbul.2004.10.022

Bonkosky, M., Hernández-Delgado, E. A., Sandoz, B., Robledo, I. E., NoratRamírez, J., and Mattei, H. (2009). Detection of spatial fluctuations of non-point source fecal pollution in coral reef surrounding waters in southwestern Puerto Rico using PCR-based assays. Mar. Pollut. Bull. 58, 45-54. doi: 10.1016/j. marpolbul.2008.09.008

Borkhataria, R., Collazo, J. A., Groom, M. J., and Jordan-García, A. (2012). Shadegrown coffee in Puerto Rico: opportunities to preserve biodiversity while 
reinvigorating a struggling agricultural economy. Agric. Ecosyst. Environ. 149, 164-170. doi: 10.1016/j.agee.2010.12.023

Bousquin, J., Fisher, W. S., Carriger, J., and Huertas, E. (2014). A Bayesian Belief network Approach to Explore Alternative Decisions for Sediment Control and Water Storage Capacity at Lago Lucchetti, Puerto Rico. U.S. Environmental Protection Agency Report EPA/600/R-14/296. Washington, DC: U.S. Environmental Protection Agency Report.

Bradley, P., Fisher, W., Dyson, B., Yee, S., Carriger, J., Gambirazzio, G., et al. (2016). Application of a Structured Decision Process for Informing Watershed Management Options in Guánica Bay, Puerto Rico. EPA 600/R15/248. Washington, DC: U.S. Environmental Protection Agency.

Bracken, L. J., Turnbull, L., Wainwright, J., and Bogaart, P. (2015). Sediment connectivity: a framework for understanding sediment transfer at multiple scales. Earth Surf. Process. Landforms 40, 177-188. doi: 10.1002/esp.3635

Brandt, M. E., Ennis, R. S., Meiling, S. S., Townsend, J., Cobleigh, K., Glahn, A., et al. (2021). The emergence and initial impact of stony coral tissue loss disease (SCTLD) in the United States Virgin Islands. Front. Mar. Sci. 8:715329. doi: $10.3389 /$ fmars.2021.715329

Brooks, A., Spencer, J., Borombovits, D., Pietsch, T., and Olley, J. (2014). Measured hillslope erosion rates in the wet-dry tropics of Cape York, northern Australia: part 2, RUSLE-based modeling significantly over-predicts hillslope sediment production. Catena 122, 1-17. doi: 10.1016/j.catena.2014.06.002

Brooks, G. R., Devine, B., Larson, R. A., and Rood, B. P. (2007). Sedimentary development of Coral Bay, St. John, USVI: a shift from natural to anthropogenic influences. Carib. J. Sci. 43, 226-243. doi: 10.18475/cjos.v43i2.a8

Brooks, G. R., Larson, R. A., Devine, B., and Schwing, P. T. (2015). Annual to millennial record of sediment delivery to US Virgin Island coastal environments. Holocene 25, 1015-1026. doi: 10.1177/09596836155 75357

Browne, N. K., Precht, E., Last, K. S., and Todd, P. A. (2014). Photo-physiological costs associated with acute sediment stress events in three near-shore turbid water corals. Mar. Ecol. Prog. Ser. 502, 129-143. doi: 10.3354/meps10714

Browning, T. N., and Sawyer, D. E. (2021). Vulnerability to watershed erosion and coastal deposition in the tropics. Sci. Rep. 11:569.

Bruckner, A. W., Bruckner, R. J., and Williams, E. H. Jr. (1997). Spread of a blackband disease epizootic through the coral reef system in St. Ann's Bay, Jamaica. Bull. Mar. Sci. 61, 919-928.

Bruno, J. F., and Valdivia, A. (2016). Coral reef degradation is not correlated with local human population density. Sci. Rep. 6:29778. doi: 10.1038/srep29778

Bruno, J. F., Petes, L. E., Drew Harvell, C., and Hettinger, A. (2003). Nutrient enrichment can increase the severity of coral diseases. Ecol. Lett. 6, 1056-1061.

Burke, L., Reytar, K., Spalding, M., and Perry, A. (2011). Reefs at Risk Revisited. Washington, DC: World Resources Institute, 115.

Burkepile, D. E., and Hay, M. E. (2008). Herbivore species richness and feeding complementarity affect community structure and function on a coral reef. Proc. Natl. Acad. Sci. U.S.A. 105, 16201-16206. doi: 10.1073/pnas.0801946105

Cabaço, S., Santos, R., and Duarte, C. M. (2008). The impact of sediment burial and erosion on seagrasses: a review. Estuar. Coast. Shelf Sci. 79, 354-366. doi: 10.1016/j.ecss.2008.04.021

Carlson, R. R., Foo, S. A., and Asner, G. P. (2019). Land use impacts on coral reef health: a ridge-to-reef perspective. Front. Mar. Sci. 6:562. doi: 10.3389/fmars. 2019.00562

Carilli, J. E., Norris, R. D., Black, B., Walsh, S. M., and McField, M. (2010). Centuryscale records of coral growth rates indicate that local stressors reduce coral thermal tolerance threshold. Glob. Change Biol. 16, 1247-1257. doi: 10.1111/ j.1365-2486.2009.02043.x

Carriger, J. F., Fisher, W. S., Stockton, T. B., and Sturm, P. E. (2013). Advancing the Guánica Bay (Puerto Rico) watershed management plan. Coast. Manag. 41, 19-38. doi: 10.1080/08920753.2012.747814

Carriger, J. F., Yee, S. H., and Fisher, W. S. (2019). An introduction to Bayesian networks as assessment and decision support tools for managing coral reef ecosystem services. Ocean Coast. Manag. 177, 188-199. doi: 10.1016/j. ocecoaman.2019.05.008

Carroll, C., Waters, D., Vardy, S., Silburn, D. M., Attard, S., Thorburn, P. J., et al. (2012). A paddock to reef monitoring and modelling framework for the Great Barrier Reef: paddock and catchment component. Mar. Pollut. Bull. 65, 136-149. doi: 10.1016/j.marpolbul.2011.11.022
CWP (2008). Guánica Bay Watershed Management Plan-A Pilot Project for Watershed Planning in Puerto Rico. Report prepared for NOAA-Coral Reef Program and PR-Department of Natural and Environmental Resources. Fulton, MD: Center for Watershed Protection, 37.

Church, M. (2017). Interpreting sediment yield scaling. Earth Surf. Process. Landforms 42, 1895-1898. doi: 10.1002/esp.4165

Clark, J. J., and Wilcock, P. R. (2000). Effects of land-use change on channel morphology in northeastern Puerto Rico. GSA Bull. 112, 1763-1777. doi: 10. 1130/0016-7606(2000)112<1763:eoluco >2.0.co;2

Collazo, J. A., Boulon, R., and Tallevast, T. L. (1992). Abundance and growth patterns of Chelonia mydas in Culebra, Puerto Rico. J. Herp. 26, 293-300. doi: $10.2307 / 1564884$

Commonwealth of PR and NOAA (2010). Puerto Rico's Coral Reef Management Priorities. Silver Spring, MD: NOAA.

Cortés, J., and Risk, M. J. (1985). A reef under siltation stress, Cahuita, Costa-Rica. Bull. Mar. Sci. 36, 339-356.

Coulthard, T. J., Ramirez, J., Fowler, H. J., and Glenis, V. (2012). Using the UKCP09 probabilistic scenarios to model the amplified impact of climate change on drainage basin sediment yield. Hydrol. Earth Syst. Sci. 16, 4401-4416. doi: 10.5194/hess-16-4401-2012

Couper, P. R. (2004). Space and time in river bank erosion research: a review. Area $36,387-403$.

Courtney, T. A., Barnes, B. B., Chollett, I., Elahi, R., Gross, K., Guest, J. R., et al. (2020). Disturbances drive changes in coral community assemblages and coral calcification capacity. Ecosphere 11:e03066. doi: 10.1002/ecs2.3066

Cox, C. A., Sarangi, A., and Madramootoo, C. A. (2006). Effect of land management on runoff and soil losses from two small watersheds in St Lucia. Land Degrad. Dev. $17,55-72$.

Craik, W., and Dutton, I. (1987). Assessing the effects of sediment discharge on the Cape Tribulation fringing coral reefs. Coast. Manag. 15, 213-228. doi: $10.1080 / 08920758709362029$

Cramer, K., Donovan, M., Jackson, J., Greenstein, B., Korpanty, C., Cook, G., et al. (2021). The transformation of Caribbean coral communities since humans. Ecol. Evol. 11, 10098-10118.

Curtis, R. E. (1985). "Floods of april 18, 1983 on St. Thomas and St. John, U.S. Virgin Islands," in Proceedings of the International Symposium on Tropical Hydrology and 2nd Caribbean Islands Water Resources Congress, San Juan, PR, 90-95.

Cybulski, J. D., Husa, S. M., Duprey, N. N., Mamo, B. L., Tsang, T. P., Yasuhara, M., et al. (2020). Coral reef diversity losses in China’s Greater Bay area were driven by regional stressors. Sci. Adv. 6:eabb1046. doi: 10.1126/sciadv.abb1046

De'ath, G., Fabricius, K. E., Sweatman, H., and Puotinen, M. (2012). The 27-year decline of coral cover on the Great Barrier Reef and its causes. Proc. Natl. Acad. Sci. U.S.A. 109, 17995-17999. doi: 10.1073/pnas. 1208909109

Demetillo, A. T., and Taboada, E. B. (2019). Real-time water quality monitoring for small aquatic area using unmanned surface vehicle. Eng. Technol. Appl. Sci. Res. 9, 3959-3964. doi: 10.48084/etasr.2661

de Vente, J., Poesen, J., Arabkhedri, M., and Verstraeten, G. (2007). The sediment delivery problem revisited. Prog. Phys. Geogr. 31, 155-178. doi: 10.1177/ 0309133307076485

de Vente, J., Poesen, J., Verstraeten, G., Govers, G., Vanmaercke, M., and Van Rompaey, A. (2013). Predicting soil erosion and sediment yield at regional scales: where do we stand? Earth Sci. Rev. 127, 16-29.

Devlin, M. J., Petus, C., Da Silva, E., Tracey, D., Wolff, N. H., Waterhouse, J., et al. (2015). Water quality and river plume monitoring in the Great Barrier Reef: an overview of methods based on ocean colour satellite data. Remote Sens. 7, 12909-12941.

Dikou, A., and van Woesik, R. (2006a). Survival under chronic stress from sediment load: spatial patterns of hard coral communities in the southern islands of Singapore. Mar. Pollut. Bull. 52, 1340-1354. doi: 10.1016/j.marpolbul. 2006.02.011

Dikou, A., and van Woesik, R. (2006b). Partial colony mortality reflects coral community dynamics: a fringing reef study near a small river in Okinawa, Japan. Mar. Pollut. Bull. 52, 269-280. doi: 10.1016/j.marpolbul.2005.08.021

Downs, C. A., Ostrander, G. K., Rougee, L., Rongo, T., Knutson, S., Williams, D. E., et al. (2012). The use of cellular diagnostics for identifying sub-lethal stress in reef corals. Ecotoxicology 21, 768-782. doi: 10.1007/s10646-011-0837-4 
Duprey, N. N., Yasuhara, M., and Baker, D. M. (2016). Reefs of tomorrow: eutrophication reduces coral biodiversity in an urbanized seascape. Glob. Change Biol. 22, 3550-3565. doi: 10.1111/gcb.13432

Dutra, L. X. C., Kikuchi, R. K. P., and Leão, Z. M. A. N. (2006). Effects of sediment accumulation on reef corals from Abrolhos, Bahia, Brazil. J. Coast. Res. 2, 633-638.

Eakin, C. M., Morgan, J. A., Heron, S. F., Smith, T. B., Liu, G., Alvarez-Filip, L., et al. (2010). Caribbean corals in crisis: record thermal stress, bleaching, and mortality in 2005. PLoS One 5:e13969. doi: 10.1371/journal.pone.0013969

Edinger, E. N., Limmon, G. V., Jompa, J., Widjatmoko, W., Heikoop, J. M., and Risk, M. J. (2000). Normal coral growth rates on dying reefs: are coral growth rates good indicators of reef health? Mar. Pollut. Bull. 40, 404-425.

Erftemeijer, P. L., Rigel, B., Hoeksema, B. W., and Todd, P. A. (2012). Environmental impacts of dredging and other sediment disturbances on corals: a review. Mar. Pollut. Bull. 64, 1737-1765. doi: 10.1016/j.marpolbul.2012.05. 008

Fabricius, K. E. (2005). Effects of terrestrial runoff on the ecology of corals and coral reefs: review and synthesis. Mar. Pollut. Bull. 50, 125-146. doi: 10.1016/j. marpolbul.2004.11.028

Fabricius, K. E. (2011). "Factors determining the resilience of Coral Reefs to eutrophication: a review and conceptual model," in Coral Reefs: An Ecosystem in Transition, eds Z. Dubinsky and N. Stambler (Dordrecht: Springer). doi: 10.1007/978-94-007-0114-4_28

Figueroa-Sánchez, Y. (2019). Hillslope and Road Segment Scale Quantification of Soil Erosion in Two Coffee Farms of Western Interior Puerto Rico: SpatioTemporal Variability and Impacts to Agricultural Sustainability. Ph.D. thesis. San Juan: University of Puerto Rico-Río Piedras, 118.

Figueroa-Sánchez, Y., Vandiver, L., Eslinger, D. L., Burkhalter, S., and Ferguson, R. (2015). Measuring the Effectiveness of an Erosion Control Practice for Watershed Management: The Case for Hydroseeding. Unpublished Report to NOAA \#8070. Washington, DC: NOAA.

Flores, F., Hoogenboom, M. O., Smith, L. D., Cooper, T. F., Abrego, D., and Negri, A. P. (2012). Chronic exposure of corals to fine sediments: lethal and sub-lethal impacts. PLoS One 7:e37795. doi: 10.1371/journal.pone.0037795

Foster, N. L., Box, S. J., and Mumby, P. J. (2008). Competitive effects of macroalgae on the fecundity of the reef-building coral Montastraea annularis. Mar. Ecol. Prog. Ser. 367, 143-152. doi: 10.3354/meps07594

Fryirs, K. A. (2013). (Dis)connectivity in catchment sediment cascades: a fresh look at the sediment delivery problem. Earth Surf. Process. Landforms 38, 30-46. doi: 10.1002/esp.3242

Fryirs, K. A., Brierley, G. J., Preston, N. J., and Kasai, M. (2007). Buffers, barriers and blankets: the (dis)connectivity of catchment-scale sediment cascades. Catena 70, 49-67. doi: 10.1016/j.catena.2006.07.007

García-Sais, J. R., Williams, S. M., and Amirrezvani, A. (2017). Mortality, recovery, and community shifts of Scleractinian corals in Puerto Rico one decade after the 2005 regional bleaching event. PeerJ 5:e3611. doi: 10.7717/peerj.3611

Ginsburg, R. N. (1993). Global Aspects of Coral Reefs: Health, Hazards and History. Miami, FL: University of Miami.

Ginsburg, R. N., Gischler, E., and Kiene, W. E. (2001). Partial mortality of massive reef-building corals: an index of patch reef condition, Florida Reef Tract. Bull. Mar. Sci. 69, 1149-1173.

Gintert, B. E., Precht, W. F., Fura, R., Rogers, K., Rice, M., Precht, L. L., et al. (2019). Regional coral disease outbreak overwhelms impacts from a local dredge project. Environ. Monitor. Assess. 191, 1-39. doi: 10.1007/s10661-019-7767-7

Glynn, P. W., Szmant, A. M., Corcoran, E. F., and Cofer-Shabica, S. V. (1989). Condition of coral reef cnidarians from the northern Florida reef tract: pesticides, heavy metals, and histopathological examination. Mar. Pollut. Bull. 20, 568-576. doi: 10.1016/0025-326x(89)90359-7

Gómez-Andújar, N. X., and Hernández-Delgado, E. A. (2020). Spatial benthic community analysis of shallow coral reefs to support coastal management in Culebra Island. Puerto Rico. PeerJ 8:e10080. doi: 10.7717/peerj.10080

Gómez-Fragoso, J. (2016). Sedimentation survey of Lago Lucchetti, Yauco, Puerto Rico, September 2013-May 2014. US Geological Survey Scientific Investigations Map 3364. Washington, DC: US Geological Survey

Gray, S. C., Gobbi, K. L., and Narwold, P. V. (2008). "Comparison of sedimentation in bays and reefs below developed versus undeveloped watersheds on St. John, US Virgin Islands," in Proceedings of the 11th Coral Reef Symposium, Ft. Lauderdale, FL, 345-349.
Hallock, P., and Schlager, W. (1986). Nutrient excess and the demise of coral reefs and carbonate platforms. Palaios 1, 389-398. doi: 10.2307/3514476

Haapkylä, J., Unsworth, R. K., Flavell, M., Bourne, D. G., Schaffelke, B., and Willis, B. L. (2011). Seasonal rainfall and runoff promote coral disease on an inshore reef. PLoS One 6:e16893. doi: 10.1371/journal.pone.0016893

Harmelin-Vivien, M. (1994). The effects of storms and cyclones on coral reefs: a review. J. Coast. Res. 12, 211-231.

Hatcher, B. G., Johannes, R. E., and Robertson, A. I. (1989). Review of research relevant to the conservation of shallow tropical marine ecosystems. Oceanogr. Mar. Biol. Annu. Rev. 27, 337-414.

Heckman, T., Cavalli, M., Cerdan, O., Foerster, S., Javaux, M., Lode, E., et al. (2018). Indices of sediment connectivity: opportunities, challenges and limitations. Earth Sci. Rev. 187, 77-108. doi: 10.1016/j.earscirev.2018. 08.004

Hernández, W. J., Ortiz-Rosa, S., Armstrong, R. A., Geiger, E. F., Eakin, C. M., and Warner, R. A. (2020). Quantifying the effects of hurricanes Irma and Maria on coastal water quality in Puerto Rico using moderate resolution satellite sensors. Remote Sens. 12:964. doi: 10.3390/rs12060964

Hernández-Delgado, E. A. (1992). Coral Reef Status of Northeastern and Eastern Puertorrican Waters: Recommendations for Long-Term Monitoring, Restoration and Management. San Juan: Caribbean Fishery Management Council, 87.

Hernández-Delgado, E. A., Ramos-Scharrón, C. E., Guerrero-Pérez, C. R., Lucking, M. A., Laureano, R., Méndez-Lázaro, P. A., et al. (2012). "Long-term impacts of non-sustainable tourism and urban development in small tropical islands coastal habitats in a changing climate: lessons learned from Puerto Rico," in Visions for Global Tourism Industry-Creating and Sustaining Competitive Strategies, ed. M. Kasimoglu (Rijeka: Tech Publications), 357-398.

Hooke, L. B. (2000). On the history of humans as geomorphic agents. Geology 28, $843-846$.

HWG and PDC (2017). Unpaved Road Standards for Caribbean and Pacific Islands. Report Submitted to NOAA Coral Reef Conservation Program and Restoration Center. Sandwich, MA: Horsley Witten Group, 82.

Hubbard, D. K. (1986). Sedimentation as a control of reef development: St. Croix, USVI. Coral Reefs 5, 117-125. doi: 10.1007/bf00298179

Hubbard, D. K. (1997). "Dynamic processes of coral-reef development," in Life and Death of Coral Reefs, ed. C. Birkeland (London: Chapman and Hall Publishers), 43-67.

Hubbard, D. K., Miller, A. I., and Scaturo, D. (1990). Production and cycling of calcium carbonate in a shelf-edge reef system (St. Croix, U.S. Virgin Islands): applications to the nature of reef systems in the fossil record. J. Sediment. Petrol. 60, 335-360.

Hubbard, D. K., Stump, J. D., and Carter, B. (1987). Sedimentation and Reef Development in Hawksnest, Fish and Reef Bays, St. John, U.S. Virgin Islands. Island Resources Foundation, Biosphere Reserve Research Report No. 21. St. Thomas: Island Resources Foundation.

Hubbard, J. A., and Pocock, Y. P. (1972). Sediment rejection by recent scleractinian corals: a key to palaeo-environmental reconstruction. Geologische Rundschau 61, 598-626. doi: 10.1007/bf01896337

Jackson, J. B., Donovan, M. K., Cramer, K. L., and Lam, V. V. (2014). Status and Trends of Caribbean coral reefs: 1970-2012. Gland: Global Coral Reef Monitoring Network.

Jessen, C. A., Pedersen, J. B. T., Bartholdy, J., Seidenkrantz, M. S., and Kuijpers, A. (2008). A late Holocene palaeoenvironmental record from Altona Bay, St. Croix, US Virgin Islands. Geografisk Tidsskrift Dan. J.Geogr. 108, 59-70. doi: 10.1080/00167223.2008.10649589

Johannes, R. E. (1975). "Pollution and degradation of coral reef communities," in Tropical Marine Pollution, eds E. J. J. Ferguson and R. E. Wood (Amsterdam: Elsevier), 13-51. doi: 10.1016/s0422-9894(08)71107-3

Jokiel, P. L., Rodgers, K. S., Storlazzi, C. D., Field, M. E., Lager, C. V., and Lager, D. (2014). Response of reef corals on a fringing reef flat to elevated suspendedsediment concentrations: Moloka'i, Hawai'i. PeerJ 2:e699. doi: 10.7717/peerj. 699

Jones, R., Bessell-Browne, P., Fisher, R., Klonowski, W., and Slivkoff, M. (2016). Assessing the impacts of sediments from dredging on corals. Mar. Pollut. Bull. 102, 9-29. doi: 10.1016/j.marpolbul.2015.10.049

Jones, R., Giofre, N., Luter, H. M., Neoh, T. L., Fisher, R., and Duckworth, A. (2020). Responses of corals to chronic turbidity. Sci. Rep. 10:4762. doi: 10.1038/s41598020-61712-w 
Joo, M., Raymond, M. A., McNeil, V. H., Huggins, R., Turner, R. D., and Choy, S. (2012). Estimates of sediment and nutrient loads in 10 major catchments draining to the Great Barrier Reef during 2006-2009. Mar. Pollut. Bull. 65, 150-166. doi: 10.1016/j.marpolbul.2012.01.002

Kaczmarsky, L. T., Draud, M., and Williams, E. H. (2005). Is there a relationship between proximity to sewage effluent and the prevalence of coral disease. Carib. J. Sci.41, 124-137.

Karl, T. R., Meehl, G. A., Miller, C. D., Hassol, S. J., Waple, A. M., and Murray, W. L. (eds) (2008). Weather and Climate Extremes in a Changing Climate. Regions of Focus: North America, Hawaii, Caribbean, and US Pacific Islands. Synthesis and Assessment Product 3.3. Washington, DC: NOAA National Climatic Data Center.

Kennedy, E. V., Perry, C. T., Halloran, P. R., Iglesias-Prieto, R., Schönberg, C. H., Wisshak, M., et al. (2013). Avoiding coral reef functional collapse requires local and global action. Curr. Biol. 23, 912-918. doi: 10.1016/j.cub.2013.04.020

Knutson, T. R., McBride, J. L., Chan, J., Emanuel, K., Holland, G., Landsea, C., et al. (2010). Tropical cyclones and climate change. Nat. Geosci. 3, 157-163.

Koci, J., Sidle, R. C., Kinsey-Henderson, A. E., Bartley, R., Wilkinson, S., Hawdon, A. A., et al. (2020). Effect of reduced grazing pressure on sediment and nutrient yields in savanna rangeland streams draining to the Greater Barrier Reef. J. Hydrol. 582:124520. doi: 10.1016/j.jhydrol.2019.124520

Korman, L. B., Goldsmith, S. T., Wagner, E. J., and Rodrigues, L. J. (2020). Spatially distributed simulations of dry and wet season sediment yields: a case study in the lower Río Loco watershed, Puerto Rico. J. South Am. Earth Sci. 103:102717. doi: $10.1016 /$ j.jsames.2020.102717

Korup, A., Densmore, A. L., and Schlunegger, F. (2010). The role of landslides in mountain range evolution. Geomorphology 120, 77-90. doi: 10.1016/j. geomorph.2009.09.017

Kroon, F. J., Schaffelke, B., and Bartley, R. (2014). Informing policy to protect coastal coral reefs: insight from a global review of reducing agricultural pollution to coastal ecosystems. Mar. Pollut. Bull. 85, 33-41. doi: 10.1016/j. marpolbul.2014.06.003

Kroon, F. J., Thorburn, P., Schaffelke, B., and Whitten, S. (2016). Towards protecting the Greater Barrier Reef from land-based pollution. Glob. Change Biol. 22, 1985-2002. doi: 10.1111/gcb.13262

Labrière, N., Locatelli, B., Laumonier, Y., Freycon, V., and Bernoux, M. (2015). Soil erosion in the humid tropics: a systematic quantitative review. Agric. Ecosyst. Environ. 203, 127-139. doi: 10.1016/j.agee.2015.01.027

Larcombe, P., Costen, A., and Woolfe, K. J. (2001). The hydrodynamic and sedimentary setting of nearshore coral reefs, central Great Barrier Reef shelf, Australia: Paluma Shoals, a case study. Sedimentology 48, 811-835. doi: 10.1046/ j.1365-3091.2001.00396.x

Larsen, M. C. (2012). "Landslides and sediment budgets in four watersheds in eastern Puerto Rico," in Water Quality and Landscape Processes of Four Watersheds in Eastern Puerto Rico, eds S. F. Murphy and R. F. Stallard (Washington, DC: US Geological Survey Professional Paper), 153-178. doi: $10.3133 / \mathrm{pp} 1789 \mathrm{f}$

Larsen, M. C., and Santiago Román, A. (2001). "Mass wasting and sediment storage in a small montane watershed: an extreme case of anthropogenic disturbance in the humid tropics," in Geomorphic Processes and Riverine Habitat, Vol. 4, eds J. M. Dorava, D. R. Montgomery, B. B. Palcsak, and F. A. Fitzpatrick, (Washington, DC: American Geophysical Union Monograph), 119-138.

Larsen, M. C., and Webb, R. M. T. (2009). Potential effects of runoff, fluvial sediment, and nutrient discharges on the coral reefs of Puerto Rico. J. Coast. Res. 25, 189-208.

Larson, R. A., Brooks, G. R., Devine, B., Schwing, P. T., Holmes, C. W., Jilbert, T., et al. (2015). Elemental signature of terrigenous sediment runoff as recorded in coastal salt ponds: US Virgin Islands. Appl. Geochem. 63, 573-585. doi: 10.1016/j.apgeochem.2015.01.008

Lasker, H. R. (1980). Sediment rejection by reef corals: the roles of behavior and morphology in Montastrea cavernosa (Linnaeus). J. Exp. Mar. Biol. Ecol. 47, 77-87.

Li, G., West, A. J., Densmore, A. L., Hammond, D. E., Jin, Z., Zhang, F., et al. (2016). Connectivity of earthquake-triggered landslides with the fluvial network: implications for landslide sediment transport after the 2008 Wenchuan earthquake. J. Geophys. Res. Earth Surf. 121, 703-724. doi: 10.1002/ 2015jf003718
Lirman, D., and Fong, P. (2007). Is proximity to land-based sources of coral stressors an appropriate measure of risk to coral reefs? An example from the Florida Reef Tract. Mar. Pollut. Bull. 54, 779-791. doi: 10.1016/j.marpolbul. 2006.12.014

Lirman, D., and Manzello, D. (2009). Patterns of resistance and resilience of the stress-tolerant coral Siderastrea radians (Pallas) to sub-optimal salinity and sediment burial. J. Exp. Mar. Biol. Ecol. 369, 72-77. doi: 10.1016/j.jembe.2008. 10.024

Littler, M. M., and Littler, D. S. (1996). Black band disease in the South Pacific. Coral Reefs 15:20.

Ludwig, W., and Probst, J. L. (1998). River sediment discharge to the oceans; present-day controls and global budgets. Am. J. Sci. 298, 265-295.

Lugo, A. E., Cintron, G., and Goenaga, C. (1981). "Mangrove ecosystems under stress," in Stress Effects on Natural Ecosystems, eds G. W. Barrett and R. Rosenberg (New York, NY: Wiley), 129-153.

Lumbroso, D. M., Boyce, S., Bast, H., and Walmsley, N. (2011). The challenges of developing rainfall intensity-duration-frequency curves and national flood hazard maps for the Caribbean. J. Flood Risk Manag. 4, 42-52. doi: 10.1111/j. 1753-318x.2010.01088.x

MacDonald, L. H., Anderson, D. M., and Dietrich, W. E. (1997). Paradise threatened: land use and erosion on St. John, US Virgin Islands. Environ. Manag. 21, 851-863. doi: 10.1007/s002679900072

MacNeil, M. A., Mellin, C., Matthews, S., Wolff, N. H., McClanahan, T. R., Devlin, M., et al. (2019). Water quality mediates resilience on the Great Barrier Reef. Nat. Ecol. Evol. 3, 620-627. doi: 10.1038/s41559-0190832-3

Maina, J., De Moel, H., Zinke, J., Madin, J., McClanahan, T., and Vermaat, J. E. (2013). Human deforestation outweighs future climate change impacts of sedimentation on coral reefs. Nat. Commun. 4:1986. doi: 10.1038/ncomms2986

Marsh, G. P. (1867). Man and Nature: Or, Physical Geography as Modified by Human Action. Whitefish, MT: Kessinger Publishing.

McKergow, L. A., Prosser, I. P., Hughes, A. O., and Brodie, J. (2005). Sources of sediment to the Great Barrier Reef World Heritage Area. Mar. Pollut. Bull. 51, 200-211. doi: 10.1016/j.marpolbul.2004.11.029

McLaughlin, C. J., Smith, C. A., Buddemeier, R. W., Bartley, J. D., and Maxwell, B. A. (2003). Rivers, runoff, and reefs. Glob. Planet. Change 39, 191-199. doi: 10.1016/s0921-8181(03)00024-9

McLaughlin, P. (2019). Impacts of Unpaved Roads on Runoff and Sediment Production in Culebra, Puerto Rico. Ph.D. thesis. Austin, TX: The University of Texas, 142.

Messina, A. M., and Biggs, T. W. (2016). Contributions of human activities to suspended sediment yield during storm events from a small, steep, tropical watershed. J. Hydrol. 538, 726-742.

Meybeck, M., and Vörösmarty, C. (2005). Fluvial filtering of land-to-ocean fluxes: from natural Holocene variations to Anthropocene. Ext. Geophys. Clim. Environ. 337, 107-123.

Miller, J., Muller, E., Rogers, C., Waara, R., Atkinson, A., Whelan, K. R. T., et al. (2009). Coral disease following massive bleaching in 2005 causes 60\% decline in coral cover on reefs in the US Virgin Islands. Coral Reefs 28, 925-937. doi: 10.1007/s00338-009-0531-7

Miller, P. W., Kumar, A., Mote, T. L., Moraes, F. D. S., and Mishra, D. R. (2019). Persistent hydrological consequences of Hurricane María in Puerto Rico. Geophys. Res. Lett. 46, 1413-1422.

Miller, R. L., and Cruise, J. F. (1995). Effects of suspended sediments on coral growth: evidence from remote sensing and hydrologic models. Remote Sens. Environ.t 53, 177-187. doi: 10.1016/0034-4257(95)00081-b

Milliman, J. D., and Farnsworth, K. L. (2013). River Discharge to the Coastal Ocean: a Global Synthesis. New York, NY: Cambridge University Press.

Morehead, M. D., Syvitski, J. P., Hutton, E. W. H., and Peckham, S. D. (2003). Modeling the temporal variability in the flux of sediment from ungauged rivers. Glob. Planet. Change 39, 95-110. doi: 10.1016/j.scitotenv.2017. 10.134

Moriasi, D. N., Arnold, J. G., Van Liew, M. W., Bingner, L., Harmel, R. D., and Veith, T. L. (2007). Model evaluation guidelines for systematic quantification of accuracy in watershed simulations. Trans. ASABE 50, 885-900. doi: 10.13031/ 2013.23153 
Moyer, R. P., and Grottoli, A. G. (2011). Coral skeletal carbon isotopes (G12C and $\mathrm{D} 14 \mathrm{C}$ ) record the delivery of terrestrial carbon to the coastal waters of Puerto Rico. Coral Reefs 30, 791-802. doi: 10.1007/s00338-011-0758-y

Muller, E. M., Sartor, C., Alcaraz, N. I., and van Woesik, R. (2020). Spatial epidemiology of the stony-coral-tissue-loss disease in Florida. Front. Mar. Sci. 7:163. doi: 10.3389/fmars.2020.00163

Muthukrishnan, R., and Fong, P. (2014). Multiple anthropogenic stressors exert complex, interactive effects on a coral reef community. Coral Reefs 33, 911-921. doi: 10.1007/s00338-014-1199-1

NOAA (2016). An implementation framework for NOAA's Habitat Blueprint Focus Area in the Caribbean - The Northeast Marine Corridor and Culebra Island, Puerto Rico. Washington, DC: NOAA, 42.

Nearing, M. A., Pruski, R. R., and O’Neal, M. R. (2004). Expected climate change impacts on soil erosion rates: a review. J. Soil Water Conserv. 59, 43-50.

Nearing, M. A., Renard, K., and Nichols, M. (2005). “Chapter 82: erosion prediction and modelling. ," in Encyclopedia of Hydrological Sciences, eds M. J. Anderson and J. J. McDonnell. (Hoboken, NJ: John Wiley and Sons). doi: 10.1007/978-3642-58913-3_5

Neil, D. T., Orpin, A. R., Ridd, P. V., and Yu, B. (2002). Sediment yield and impacts from river catchments to the Great Barrier Reef Lagoon: a review. Mar. Freshw. Res. 53, 733-752. doi: 10.1071/MF00151

Nelson, D. S., McManus, J., Richmond, R. H., King, D. B. Jr., Gailani, J. Z., Lackey, T. C., et al. (2016). Predicting dredging-associated effects to coral reefs in Apra Harbor, Guam-Part 2: potential coral effects. J. Environ. Manag. 168, 111-122. doi: 10.1016/j.jenvman.2015.10.025

Nemeth, R. S., and Nowlis, J. S. (2001). Monitoring the effects of land development on the near-shore reef environment of St. Thomas, USVI. Bull. Mar. Sci. 69, 759-775.

Norat-Ramírez, J., Méndez-Lázaro, P., Hernández-Delgado, E. A., Mattei-Torres, H., and Cordero-Rivera, L. (2019). A septic waste index model to measure the impact of septic tanks on coastal water quality and coral reef communities in Rincon, Puerto Rico. Ocean Coast. Manag. 169, 201-213. doi: 10.1016/j. ocecoaman.2018.12.016

Nugues, M. M., and Roberts, C. M. (2003). Coral mortality and interaction with algae in relation to sedimentation. Coral Reefs 22, 507-516. doi: 10.1007/ s00338-003-0338-x

Nugues, M. M., and Bak, R. P. (2006). Differential competitive abilities between Caribbean coral species and a brown alga: a year of experiments and a long-term perspective. Mar. Ecol. Prog. Ser. 315, 75-86.

Nugues, M. M., Smith, G. W., Van Hooidonk, R. J., Seabra, M. I., and Bak, R. P. (2004). Algal contact as a trigger for coral disease. Ecol. Lett. 7, 919-923.

Odum, H. (1967). "Work circuits and system stress," in Symposium on Primary Productivity and Mineral Cycling in Natural Ecosystems, ed. H. E. Young. (Orono, ME: University of Maine Press).

Ogston, A. S., Storlazzi, C. D., Field, M. E., and Presto, M. K. (2004). Currents and suspended sediment transport on a shallow reef flat: South-central Molokai, Hawaii. Coral Reefs 23, 559-569.

Oliver, L. M., Lehrter, J. C., and Fisher, W. S. (2011). Relating landscape development intensity to coral reef condition in the watersheds of St. Croix, US Virgin Islands. Mar. Ecol. Prog. Ser. 427, 293-302. doi: 10.3354/meps09087

Oliver, L. M., Fisher, W. S., Dittmar, J., Hallock, P., Campbell, J., Quarles, R. L., et al. (2014). Contrasting responses of coral reef fauna and foraminiferal assemblages to human influence in La Parguera, Puerto Rico. Mar. Environ. Res. 99, 95-105. doi: 10.1016/j.marenvres.2014.04.005

Oliver, L. M., Fisher, W. S., Fore, L., Smith, A., and Bradley, P. (2018). Assessing land use, sedimentation, and water quality stressors as predictors of coral reef condition in St. Thomas, U.S. Virgin Islands. Environ. Monitor. Assess. 190:213. doi: 10.1007/s10661-018-6562-1

Ortiz-Zayas, J. R., and Terrasa-Soler, J. J. (2001). "Allocating water resources for public supply within a complex hydroelectric system: the case study of Yauco, Puerto Rico," in Proceedings of the 2nd Latin American Technical Conference and Exhibition, San Juan, 249-278. doi: 10.2175/1938647017842 93224

Otaño-Cruz, A., Montañez-Acuña, A. A., Torres-López, V., Hernández-Figueroa, E. M., and Hernández-Delgado, E. A. (2017). Effects of changing weather, oceanograpic conditions, and land uses on spatio-temporal variation of sedimentation dynamics along near-shore coral reefs. Front. Mar. Sci. 4:249. doi: $10.3389 /$ fmars.2017.00249
Otaño-Cruz, A., Montañez-Acuña, A. A., García-Rodríguez, N. M., Díaz-Morales, D. M., Benson, E., Cuevas, E., et al. (2019). Caribbean near-shore coral reef benthic community response to changes on sedimentation dynamics and environmental conditions. Front. Mar. Sci. 6:551. doi: 10.3389/fmars.2019. 00551

Otero, E., and Carbery, K. K. (2005). Chlorophyll a and turbidity patterns over coral reef systems of La Parguera Natural Reserve, Puerto Rico. Rev. Biol. Trop. $53,25-32$.

Oxenford, H. A., and Vallès, H. (2016). Transient turbid water mass reduces temperature-induced coral bleaching and mortality in Barbados. PeerJ 4:e2118. doi: $10.7717 /$ peerj. 2118

Pagendam, D. E., Kuhnert, P. M., Leeds, W. B., Wikle, C. K., Bartley, R., and Peterson, E. E. (2013). Assimilating catchment processes with monitoring data to estimate sediment loads to the Great Barrier Reef. Environmetrics 25, 214-229. doi: 10.1002/env.2255

Pait, A. S., Whitall, D. R., and Dieppa, A. (2012). Characterization of organic chemical contaminants in sediments from Jobos Bay, Puerto Rico. Environ. Monitor. Assess. 184, 5065-5075. doi: 10.1007/s10661-011-2322-1

Parsons, A. J. (2012). How useful are catchments sediment budgets? Prog. Phys. Geogr. 36, 60-71. doi: 10.1177/0309133311424591

Parsons, A. J., Wainwright, J., Brazier, R. E., and Powell, D. M. (2006). Is sediment delivery a fallacy? Earth Surf. Process. Landforms 31, 1325-1328.

Pastorok, R. A., and Bilyard, G. R. (1985). Effects of sewage pollution on coral-reef communities. Mar. Ecol. Prog. Ser. 21, 175-189. doi: 10.3354/meps021175

Perez, K. III, Rodgers, K. S., Jokiel, P. L., Lager, C. V., and Lager, D. J. (2014). Effects of terrigenous sediment on settlement and survival of the reef coral Pocillopora damicornis. PeerJ 2:e387. doi: 10.7717/peerj.387

Perry, C. T., Edinger, E. N., Kench, P. S., Murphy, G. N., Smithers, S. G., Steneck, R. S., et al. (2012). Estimating rates of biologically driven coral reef framework production and erosion: a new census-based carbonate budget methodology and applications to the reefs of Bonaire. Coral Reefs 31, 853-868. doi: 10.1007/ s00338-012-0901-4

Phillip, E., and Fabricius, K. E. (2003). Photophysiological stress in scleractinian corals in response to short-term sedimentation. J. Exp. Mar. Biol. Ecol. 287, 57-78.

Piniak, G. A., and Storlazzi, C. D. (2008). Diurnal variability in turbidity and coral fluorescence on a fringing reef flat: Southern Molokai, Hawaii. Estuar. Coast. Shelf Sci. 77, 56-64. doi: 10.1016/j.ecss.2007. 08.023

Pollock, F. J., Lamb, J. B., Field, S. N., Heron, S. F., Schaffelke, B., Shedrawi, G., et al. (2014). Sediment and turbidity associated with offshore dredging increase coral disease prevalence on nearby reefs. PLoS One 9:e102498. doi: 10.1371/journal. pone. 0102498

Precht, W. F., Gintert, B. E., Robbart, M. L., Fura, R., and van Woesik, R. (2016). Unprecedented disease-related coral mortality in southeastern Florida. Sci. Rep. 6:31374. doi: 10.1038/srep31374

Ramos-Scharrón, C. E. (2004). Measuring and Predicting Erosion and Sediment Yields on St John, US Virgin Islands. Ph.D. thesis. Fort Collins, CO: Colorado State University.

Ramos-Scharrón, C. E. (2012). Effectiveness of drainage improvements in reducing sediment production rates from an unpaved road. J. Soil Water Conserv. 67, 87-100.

Ramos-Scharrón, C. E. (2021). Impacts of off-road vehicle tracks on runoff, erosion and sediment delivery-a combined field and modeling approach. Environ. Model. Softw. 136:104957. doi: 10.1016/j.envsoft.2020.104957

Ramos-Scharrón, C. E., and Figueroa-Sánchez, Y. (2017). Plot-, farm-, and watershed-scale effects of coffee cultivation in runoff and sediment production in western Puerto Rico. J. Environ. Manag. 202, 126-136. doi: 10.1016/j. jenvman.2017.07.020

Ramos-Scharrón, C. E., and LaFevor, M. C. (2016). The role of unpaved roads as active source areas of precipitation excess in small watersheds drained by ephemeral streams in the Northeastern Caribbean. J. Hydrol. 533, 168-179. doi: 10.1016/j.jhydrol.2015.11.051

Ramos-Scharrón, C. E., and LaFevor, M. C. (2018). Effects of forest roads on runoff initiation in low-order ephemeral streams. Water Resour. Res. 54, 8613-8631. doi: 10.1029/2018wr023442

Ramos-Scharrón, C. E., and MacDonald, L. H. (2005). Measurement and prediction of sediment production from unpaved roads, 
St. John, US Virgin Islands. Earth Surf. Process. Landforms 30, 1283-1304.

Ramos-Scharrón, C. E., and MacDonald, L. H. (2007a). Development and application of a GIS-based sediment budget model. J. Environ. Manag. 84, 157-172. doi: 10.1016/j.jenvman.2006.05.019

Ramos-Scharrón, C. E., and MacDonald, L. H. (2007b). Measurement and prediction of natural and anthropogenic sediment sources, St. John, U.S. Virgin Islands. Catena 71, 250-266. doi: 10.1016/j.catena.2007.03.009

Ramos-Scharrón, C. E., and Thomaz, E. L. (2017). Runoff development and soil erosion in a wet tropical montane setting under coffee cultivation. Land Degrad. Dev. 28, 936-945.

Ramos-Scharrón, C. E., Alicea-Díaz, E., Figueroa-Sánchez, Y., and Viqueira-Ríos, R. (2022). Road cutslope erosion and control treatments in an activelycultivated tropical montane setting. Catena 209:105814. doi: 10.1016/j.catena. 2021.105814

Ramos-Scharrón, C. E., Amador-Gutierrez, J. M., and Hernández-Delgado, E. (2012a). "An interdisciplinary erosion mitigation approach for coral reef protection-a case study from the Eastern Caribbean," in Marine Ecosystems, ed. A. Cruzado (London: InTech Publications), 127-160.

Ramos-Scharrón, C. E., Reale-Munroe, K., Swanson, B., Atkinson, S., and Devine, B. (2012b). USVI Coastal Habitat Restoration Through Watershed Stabilization Project, NOAA-ARRA, 2009-2012, Terrestrial Monitoring Component. Unpublished Report to NOAA-Coral Reef Protection Program. Washington, DC: NOAA, 242.

Ramos-Scharrón, C. E., Arima, E. Y., and Hughes, K. S. (2020). An assessment of the spatial distribution of shallow landslides induced by Hurricane María in Puerto Rico. Phys. Geogr. 1-29. doi: 10.1080/02723646.2020.1801121

Ramos-Scharrón, C. E., Arima, E. Y., Guidry, A., Ruffe, D., and Vest, B. (2021). Sediment mobilization from hurricane-driven landsliding in an actively cultivated wet subtropical landscape. J. Geophys. Res. Earth Surf. 125:e2020JF006054.

Ramos-Scharrón, C. E., Torres-Pulliza, D., and Hernández-Delgado, E. A. (2015). Watershed- and island wide-scale land cover changes in Puerto Rico (1930s2004) and their potential effects on coral reef ecosystems. Sci. Total Environ. 506-507, 241-251. doi: 10.1016/j.scitotenv.2014.11.016

Reed, P. (2012). NOAA ARRA USVI Watershed Stabilization Project-Summary Report. Washington, DC: NOAA, 17.

Reid, L. M., and Dunne, T. (1996). Rapid Evaluation of Sediment Budgets. Reiskirchen: Catena Verlag, 164.

Renard, K. G., Foster, G. R., Weesies, G. A., McCool, D. K., and Yoder, D. C. (1997). Predicting Soil Erosion by Water: A Guide to Conservation Planning With the Revised Soil Loss Equation (RUSLE). Agricultural Handbook No. 703. Washington DC: U.S. Department of Agriculture.

Restrepo, J. D., Park, E., Aquino, S., and Latrubesse, E. M. (2016). Coral reefs chronically exposed to river sediment plumes in the southwestern Caribbean: Rosario Islands, Colombia. Sci. Total Environ. 553, 316-329. doi: 10.1016/j. scitotenv.2016.02.140

Rice, S. A., and Hunter, C. L. (1992). Effects of suspended sediment and burial on scleractinian corals from west central Florida patch reefs. Bull. Mar. Sci. 51, $429-442$.

Richmond, R. H. (1993). Coral reefs: present problems and future concerns resulting from anthropogenic disturbance. Am. Zool. 33, 524-536.

Richmond, R. H., Rongo, T., Golbuu, Y., Victor, S., Idechong, N., Davis, G., et al. (2007). Watersheds and coral reefs: conservation science, policy, and implementation. Bioscience 57, 598-607. doi: 10.1641/B570710

Risk, M. J. (2014). Assessing the effects of sediments and nutrients on coral reefs. Curr. Opin. Environ. Sustain. 7, 108-117. doi: 10.1016/j.cosust.2014.01.003

Risk, M. J., and Edinger, E. (2011). "Impacts of Sediment on Coral Reefs," in Encyclopedia of Modern Coral Reefs, ed. D. Hopley (Dorcrecht: Springer), 576-586.

Rodgers, K. S., Kido, M. H., Jokiel, P. L., Edmonds, T., Brown, E. K., and Ku ulei, S. (2012). Use of integrated landscape indicators to evaluate the health of linked watersheds and coral reef environments in the Hawaiian Islands. Environ. Manag. 50, 21-30. doi: 10.1007/s00267-012-9867-9

Rogers, C. S. (1983). Sublethal and lethal effects of sediments applied to common Caribbean reef corals in the field. Mar. Pollut. Bull. 14, 378-382. doi: 10.1016/ 0025-326x(83)90602-1
Rogers, C. S. (1990). Responses of corals reefs and reef organisms to sedimentation. Mar. Ecol. Prog. Ser. 62, 185-202. doi: 10.3354/meps062185

Rogers, C. S., and Miller, J. (2006). Permanent 'phase shifts' or reversible declines in coral cover? Lack of recovery of two coral reefs in St. John, US Virgin Islands. Mar. Ecol. Prog. Ser. 306, 103-114. doi: 10.3354/meps3 06103

Rogers, C. S., and Miller, J. (2016). "Measuring, interpreting, and responding to changes in coral reefs: a challenge for biologists, geologists, and managers," in Coral Reefs at the Crossroads, eds D. K. Hubbard, C. S. Rogers, J. H. Lipps, and G. D. Stanley (Dordrecht: Springer), 277-292.

Rogers, C. S., and Teytaud, R. (1988). Marine and Terrestrial Ecosystems of the Virgin Islands National Park and Biosphere Reserve. Biosphere Reserve Report No. 29. St. Thomas: Island Resources Foundation.

Rogers, C. S., Miller, J., Muller, E. M., Edmunds, P., Nemeth, R. S., Beets, J. P., et al. (2008). "Ecology of coral reefs in the US Virgin Islands," in Coral Reefs of the USA, eds B. M. Riegl and R. E. Dodge (Dordecht: Springer), 303-373.

Rudel, T. K., Pérez-Lugo, M., and Zichal, H. (2000). When fields revert to forest: development and spontaneous reforestation in post-war Puerto Rico. Prof. Geogr. 52, 386-397. doi: 10.1111/0033-0124.00233

Rushmore, M. E., Ross, C., and Fogarty, N. D. (2021). Physiological responses to short-term sediment exposure in adults of the Caribbean coral Montastraea cavernosa and adults and recruits of Porites astreoides. Coral Reefs 40, 15791591.

Ryan, K. E., Walsh, J. P., Corbett, D. R., and Winter, A. (2008). A record of recent change in terrestrial sedimentation in a coral-reef environment, La Parguera, Puerto Rico: a response to coastal development? Mar. Pollut. Bull. 56, 177-1183. doi: 10.1016/j.marpolbul.2008.02.017

Ryan-Mishkin, K. E., Walsh, J. P., Corbett, D. R., Dail, M. B., and Nittrouer, J. A. (2009). Modern sedimentation in a mixed siliciclastic-carbonate coral reef environment, La Parguera, Puerto Rico. Carib. J. Sci. 45, 151-167. doi: 10.18475/cjos.v45i2.a4

Schutte, V. G. W., Selig, E. R., and Bruno, J. F. (2010). Regional spatio-temporal trends in Caribbean coral reef benthic communities. Mar. Ecol. Prog. Ser. 402, 115-122. doi: 10.3354/meps08438

Selye, H. (1956). The Stress of Life. New York, NY: McGraw-Hill Book Company, 324.

Shi, Z. H., Ai, L., Li, X., Huang, X. D., Wu, G. L., and Liao, W. (2013). Partial leastsquares regression for linking land-cover patterns to soil erosion and sediment yield in watersheds. J. Hydrol. 498, 165-176. doi: 10.1016/j.jhydrol.2013.06.031

Shi, Z. H., Huang, X. D., Ai, L., Fang, N. F., and Wu, G. L. (2014). Quantitative analysis of factors controlling sediment yield in mountainous watersheds. Geomorphology 226, 193-201. doi: 10.1016/j.geomorph.2014. 08.012

Smith, A., Yee, S. H., Russell, M., Awkerman, J., and Fisher, W. S. (2017). Linking ecosystem service supply to stakeholder concerns on both land and sea: an example from Guánica Bay watershed, Puerto Rico. Ecol. Indic. 74, 371-383. doi: 10.1016/j.ecolind.2016.11.036

Smith, S. M. C., Belmont, P., and Wilcock, P. R. (2011). "Closing the gap between watershed modeling, sediment budgeting, and stream restoration," in Stream Restoration in Dynamic Fluvial Systems: Scientific Approaches, Analyses, and Tools. Geophysical Monograph Series, Vol. 194, eds A. Simon, S. J. Bennett, and J. M. Castro (Washington, DC: American Geophysical Union), 293-317. doi: 10.1029/2011gm001085

Smith, T. B., Nemeth, R. S., Blondeau, J., Calnan, J. M., Kadison, E., and Herzlieb, S. (2008). Assessing coral reef health across onshore stress gradients in the US Virgin Islands. Mar. Pollut. Bull. 56, 1983-1991. doi: 10.1016/j.marpolbul.2008. 08.015

Sofonia, J. J., and Unsworth, R. K. (2010). Development of water quality thresholds during dredging for the protection of benthic primary producer habitats. J. Environ. Monitor. 12, 159-163. doi: 10.1039/b904986j

Soler-López, L. R. (2002). Sedimentation survey of Lago Loco, Puerto Rico, March 2000. U.S. Geological Survey Water-Resources Investigations Report 01-4187. Washington, DC: U.S. Geological Survey Water-Resources Investigations.

Spalding, M. D., and Brown, B. E. (2015). Warm-water coral reefs and climate change. Science 350, 769-771. doi: 10.1126/science.aad 0349

Stafford-Smith, M. G. (1993). Sediment-rejection efficiency of 22 species of Australian scleractinian corals. Mar. Biol. 115, 229-243. 
Stafford-Smith, M. G., and Ormond, R. F. (1992). Sediment-rejection mechanisms of 42 species of Australian scleractinian corals. Mar. Freshw. Res. 43, 683-705.

Stearn, C. W., Scoffin, T. P., and Martindale, W. (1977). Calcium carbonate budget of a fringing reef on the west coast of Barbados: part I. Zonation and productivity. Bull. Mar. Sci. 27, 479-510.

Stock, J. D., Cochran, S. A., Field, M. E., Jacobi, J. D., and Tribble, G. (2011). From Ridge to Reef-Linking Erosion and Changing Watersheds to Impacts on the Coral Reef Ecosystems of Hawai'i and the Pacific Ocean. U.S. Geological Survey Fact Sheet 3049. Washington, DC: U.S. Geological Survey.

Stock, J. D., Ericksen, T., Tribble, G., and Jacobi, J. (2014). From ridge to Reef, Quantifying Sediment Pollution to Hawaiian Coral Reefs. Fall Meeting 2014, Abstract id: EP13F-03. Washington, DC: American Geophysical Union.

Stoddart, J., Jones, R., Page, C., Marnane, M., De Lestang, P., and Elsdon, T. (2019). No effect of dredging on the prevalence of coral disease detected during a large dredging program. Mar. Pollut. Bull. 140, 353-363. doi: 10.1016/j.marpolbul. 2019.01.047

Storlazzi, C. D., Field, M. E., Bothner, M. H., Presto, M. K., and Draut, A. E. (2009). Sedimentation processes in a coral reef embayment: Hanalei Bay, Kauai. Mar. Geol. 264, 140-151.

Storlazzi, C. D., Field, M. E., and Bothner, M. H. (2011). The use (and misuse) of sediment traps in coral reef environments: theory, observations, and suggested protocols. Coral Reefs 30, 23-38.

Storlazzi, C. D., Norris, B. K., and Rosenberger, K. J. (2015). The influence of grain size, grain color, and suspended-sediment concentration on light attenuation: why fine-grained terrestrial sediment is bad for coral reef ecosystems. Coral Reefs 34, 967-975. doi: 10.1007/s00338-015-1268-0

Sturm, P., Viqueira, R., Ferguson, R., and Moore, T. (2012). "Addressing land based sources of pollution in Guánica, Puerto Rico," in Proceedings of the 12th International Coral Reef Symposium, Cairns, QLD.

Suárez-Castro, A. F., Beyer, H. L., Kuempel, C. D., Linke, S., Borrelli, P., and HoeghGuldberg, O. (2021). Global forest restoration opportunities to foster coral reef conservation. Glob. Change Biol. 27, 5238-5252. doi: 10.1111/gcb.15811

Sutherland, K. P., Porter, J. W., and Torres, C. (2004). Disease and immunity in Caribbean and Indo-Pacific zooxanthellate corals. Mar. Ecol. Prog. Ser. 266, 273-302.

Syvitski, J. P. M., and Kettner, A. (2011). Sediment flux and the Anthropocene. Philos. Trans. R. Soc. A 369, 957-975. doi: 10.1098/rsta.2010.0329

Syvitski, J. P., Cohen, S., Kettner, A. J., and Brakenridge, G. R. (2014). How important and different are tropical rivers?-An overview. Geomorphology 227, 5-17.

Takesue, R. K., Sherman, C., Ramírez, N. I., Reyes, A. O., Cheriton, O. M., Viqueira Ríos, R., et al. (2021). Land-based sediment sources and transport to southwest Puerto Rico coral reefs after Hurricane María, May 2017 to June 2018. Estuar. Coast. Shelf Sci. 259:107476. doi: 10.1016/j.ecss.2021. 107476

Tarya, A., Hoitink, A. J., Van der Vegt, M., van Katwijk, M. M., Hoeksema, B. W., Bouma, T. J., et al. (2018). Exposure of coastal ecosystems to river plume spreading across a near-equatorial continental shelf. Cont. Shelf Res. 153, 1-15.

Taylor, M. A., Stephenson, T. S., Chen, A. A., and Stephenson, K. A. (2012). Climate change and the Caribbean: review and response. Carib. Stud. 40, 169-200.

The Territory of USVI and NOAA (2010). United States Virgin Island's Coral Reef Management Priorities. Silver Spring, MD: NOAA.

Torres-Pérez, J. L., Ramos-Scharrón, C. E., Hernández, W. J., Armstrong, R. A., Barreto-Orta, M., Ortiz-Zayas, J., et al. (2021). River streamflow, remotely sensed water quality, and benthic composition of previously undescribed nearshore coral reefs in northern Puerto Rico. Front. Mar. Sci. 8:720712. doi: $10.3389 /$ fmars.2021.720712

Turnbull, L., Hütt, M. T., Ioanides, A. A., Kininmonth, S., Poeppl, R., Tockner, K., et al. (2018). Connectivity and complex systems: learning from a multidisciplinary perspective. Appl. Netw. Sci. 3:11. doi: 10.1007/s41109-0180067-2

Tuttle, L. J., and Donahue, M. J. (2020). Thresholds for Sediment Stress on Corals: A Systematic Review and Meta-Analysis. University of Hawaii. Silver Spring, MD: NOAA, 75.

Tuttle, L. J., Johnson, C., Kolinski, S., Minton, D., and Donahue, M. J. (2020). How does sediment exposure affect corals? A systematic review protocol. Environ. Evid. 9, 1-7.
Tyson, G. (1987). Historic Land use in the Reef Bay, Fish Bay and Hawksnest Bay Watersheds, St. John, U.S. Virgin Islands, 1718-1950. Biosphere Reserve Research Report no. 19. St. Thomas: USDOI National Park Service.

US-EPA (1983). Water Quality in the Virgin Islands. US-EPA Region II, Edison. Washington, DC: US-EPA.

van Dam, J. W., Negri, A. P., Uthicke, S., and Mueller, J. F. (2011). "Chemical pollution on coral reefs: exposure and ecological effects," in Ecological Impacts of Toxic Chemicals, Vol. 9 eds F. Sánchez-Bayo, P. J. van den Brink and R. M. Mann (Sharjah: Bentham Science Publishers Ltd), 187-211. doi: 10.2174/ 978160805121210187

van Woesik, R., Tomascik, T., and Blake, S. (1999). Coral assemblages and physico-chemical characteristics of the Whitsunday Islands: evidence of recent community changes. Mar. Freshw. Res. 50, 427-440. doi: 10.1071/mf9 7046

van Woesik, R., Houk, P., Isechal, A. L., Idechong, J. W., Victor, S., and Golbuu, Y. (2012). Climate-change refugia in the sheltered bays of P alau: analogs of future reefs. Ecol. Evol. 2, 2474-2484. doi: 10.1002/ ece 3.363

Vega Thurber, R. L., Burkepile, D. E., Fuchs, C., Shantz, A. A., McMinds, R., and Zaneveld, J. R. (2014). Chronic nutrient enrichment increases prevalence and severity of coral disease and bleaching. Glob. Change Biol. 20, 544-554. doi: $10.1111 / \mathrm{gcb} .12450$

Veron, J. E. N., and Phinney, J. (2006). "Corals and climate change: an introduction," in Coral Reefs and Climate Change: Science and Management, eds J. T. Phinney, O. Hoegh-Guldberg, J. Kleypas, W. Skirving, and A. Strong (Washington, DC: American Geophysical Union), 61.

Viqueira-Ríos, R. A. (2018). Implementation of the Guánica Bay Watershed Management Plan-Integrated Watershed Management Actions, Final Report 2012-2017. Yauco: Protectores de Cuencas Inc, 106.

Voss, J. D., and Richardson, L. L. (2006a). Nutrient enrichment enhances black band disease progression in corals. Coral Reefs 25, 569-576. doi: 10.1007/ s00338-006-0131-8

Voss, J. D., and Richardson, L. L. (2006b). Coral diseases near Lee Stocking Island, Bahamas: patterns and potential drivers. Dis. Aquat. Organ. 69, 33-40. doi: 10.3354/dao069033

Walling, D. E. (1983). The sediment delivery problem. J. Hydrol. 65, 209-237. doi: $10.1016 / 0022-1694(83) 90217-2$

Walling, D. E. (1999). Linking land use, erosion and sediment yields in river basins. Hydrobiologia 410, 223-240. doi: 10.1016/j.scitotenv.2016. 09.019

Wear, S. L., and Thurber, R. V. (2015). Sewage pollution: mitigation is key for coral reef stewardship. Ann. N. Y. Acad. Sci. 1355, 15-30. doi: 10.1111/nyas. 12785

Weber, M., Lott, C., and Fabricius, K. E. (2006). Sedimentation stress in a scleractinian coral exposed to terrestrial and marine sediments with contrasting physical, organic and geochemical properties. J. Exp. Mar. Biol. Ecol. 336, 18-32. doi: 10.1016/j.jembe.2006. 04.007

Weil, E. (2021). Written Communication. San Juan, PR: University of Puerto Rico. Wenger, A. S., Harris, D., Weber, S., Vaghi, F., Nand, Y., Naisilisili, W., et al. (2020). Best-practice forestry management delivers diminishing returns for coral reefs with increased land-clearing. Appl. Ecol. 57, 2381-2392. doi: 10.1111/13652664.13743

Whitall, D., Mason, A., Pait, A., Brune, L., Fulton, M., Wirth, E., et al. (2014). Organic and metal contamination in marine surface sediments of Guánica Bay, Puerto Rico. Mar. Pollut. Bull. 80, 293-301. doi: 10.1016/j.marpolbul.2013.12. 053

White, S. (2005). Sediment yield prediction and modelling. Hydrol. Process. 19, 3053-3057. doi: 10.1002/hyp.6003

Wilkinson, C. (2008). Status of Coral Reefs of the World: 2008. Cairns, QLD: Reef and Rainforest Research Centre.

Wohl, E. (2015). Legacy effects on sediments in river corridors. Earth Sci. Rev. 147, 30-53. doi: 10.1016/j.earscirev.2015.05.001

Wolanski, E., Richmond, R. H., and McCook, L. (2004). A model of the effects of land-based, human activites on the health of coral reefs in the Great Barrier Reef and Fouha Bay, Guam, Micronesia. J. Mar. Syst. 46, 133-144. doi: 10.1016/ j.jmarsys.2003.11.018 
Wolanski, E., Martínez, J. A., and Richmond, R. H. (2009). Quantifying the impact of watershed urbanization on a coral reef: Maunalua Bay, Hawaii. Estuarine. Coast. Shelf Sci. 84, 259-268.

Woolfe, K. J., and Larcombe, P. (1999). Terrigenous sedimentation and coral reef growth: a conceptual framework. Mar. Geol. 155, 331-345. doi: 10.1016/s00253227(98)00131-5

Work, T. M., Weatherby, T. M., Landsberg, J. H., Kiryu, Y., Cook, S. M., and Peters, E. C. (2021). Viral-like particles are associated with endosymbiont pathology in Florida corals affected by stony coral tissue loss disease. Front. Mar. Sci. 8:750658. doi: 10.3389/fmars.2021. 750658

Yuan, Y., Hu, W., and Li, G. (2016). Evaluation of soil erosion and sediment yield from ridge watersheds leading to Guánica Bay, Puerto Rico, using the soil and water assessment tool model. Soil Sci. 181:315. doi: 10.1097/ss. 0000000000000166
Conflict of Interest: The authors declare that the research was conducted in the absence of any commercial or financial relationships that could be construed as a potential conflict of interest.

Publisher's Note: All claims expressed in this article are solely those of the authors and do not necessarily represent those of their affiliated organizations, or those of the publisher, the editors and the reviewers. Any product that may be evaluated in this article, or claim that may be made by its manufacturer, is not guaranteed or endorsed by the publisher.

Copyright (C) 2022 Rogers and Ramos-Scharrón. This is an open-access article distributed under the terms of the Creative Commons Attribution License (CC BY). The use, distribution or reproduction in other forums is permitted, provided the original author(s) and the copyright owner(s) are credited and that the original publication in this journal is cited, in accordance with accepted academic practice. No use, distribution or reproduction is permitted which does not comply with these terms. 